\title{
Formalized classification of ephemeral wetland vegetation (Isoëto-Nanojuncetea class) in Poland (Central Europe)
}

\author{
Zygmunt Kącki ${ }^{\text {Equal first author, } 1}{ }^{\text {, Andrzej Lysko }}{ }^{2}$, Zygmunt Dajdok ${ }^{3}$, Piotr Kobierski ${ }^{4}$, Rafał Krawczyk ${ }^{5}$, Arkadiusz \\ Nowak $^{6}$, Stanisław Rosadziński ${ }^{7}$, Agnieszka Anna Popiela ${ }^{\text {Corresp. Equal first author, } 8}$ \\ 1 Botanical Garden, University of Wrocław, Wrocław, Poland \\ 2 Faculty of Computer Science and Information Technology, Western Pomeranian University of Technology in Szczecin, Szczecin, Poland \\ 3 Institute of Environmental Biology, University of Wrocław, Wrocław, Poland \\ 4 Zespół Szkół Technicznych im. Władysława Reymonta w Lubsku, Lubsko, Poland \\ 5 Institute of Biological Sciences, Maria Curie-Skłodowska University, Lublin, Poland \\ 6 Botanical Garden, Center for Biological Diversity Conservation, Polish Academy of Sciences, Warszawa, Poland \\ 7 Department of Plant Ecology and Environmental Protection, Faculty of Biology, Adam Mickiewicz University in Poznań, Poznań, Poland \\ 8 Institute of Biology, University of Szczecin, Szczecin, Poland \\ Corresponding Author: Agnieszka Anna Popiela \\ Email address: popiela@univ.szczecin.pl
}

Formalized classification of the class Isoëto-Nanojuncetea has not been performed in Poland. We used 69562 relevés stored in Polish Vegetation Database. Based on the literature and expert knowledge we selected 63 diagnostic species for the Isoëto-Nanojuncetea class. Unequivocal classification was applied in this work according to Cocktail method. A set of formal definitions was established using a combination of logical operators of total cover of species in case of high-rank syntaxa while sociological species groups and cover of particular species were used for logical formulas describing class, alliances and associations. An Expert System was prepared and applied to classify the whole data set of PVD and 1340 relevés were organized at the class level. We stratifies the data and finally we used data set of 903 relevés to prepare synoptic tables, distribution maps and descriptions of the syntaxa. 12 associations and two plant communities were identified. Vegetation of the Isoëto-Nanojuncetea class occur in Poland 's central and southern part, with scattered stands in northern region. We described two new plant communities within Eleocharition and Radiolion alliance. The first formal classification of the IsoëtoNanojuncetea class revealed a high diversity of ephemeral vegetation wetland found in Poland in the eastern boundary of their geographical distribution in Europe. 
1 Formalized classification of ephemeral wetland vegetation (Isoëto-Nanojuncetea class) in Poland

2 (Central Europe)

3

4 Zygmunt Kącki ${ }^{1 \mathrm{~A}}$, Andrzej Łysko ${ }^{2}$, Zygmunt Dajdok ${ }^{3}$, Piotr Kobierski ${ }^{4}$, Rafał Krawczyk ${ }^{5}$,

5 Arkadiusz Nowak ${ }^{6}$, Stanisław Rosadziński ${ }^{7}$ \& Agnieszka Anna Popiela ${ }^{8 * A}$

6

A equal co-first author

${ }^{1}$ Botanical Garden, University of Wrocław, Sienkiewicza 23, 50-335 Wrocław, Poland, zygmunt.kacki@uwr.edu.pl;

${ }^{2}$ Faculty of Computer Science and Information Technology, Western Pomeranian University of Technology in Szczecin, Żołnierska 49, 71-210 Szczecin, Poland, andrzej.lysko@zut.edu.pl; ${ }^{3}$ Institute of Environmental Biology, University of Wrocław, Kanonia 6/8, 50-328 Wrocław, Poland; zygmunt.dajdok@uwr.edu.pl;

${ }^{4}$ Piotr Kobierski, Zespół Szkół Technicznych im. Władysława Reymonta w Lubsku, ul.

Powstańców Wielkopolskich 2, 68-300 Lubsko, e-mail: kobierski.p@gmail.com

${ }^{5}$ Institute of Biological Sciences, Maria Curie-Skłodowska University, Akademicka 19, 20-033 Lublin, Poland, rafal.krawczyk@umcs.lublin.pl;

${ }^{6}$ Botanical Garden, Center for Biological Diversity Conservation, Polish Academy of Sciences, Prawdziwka 2, 02-976 Warszawa, Poland; Institute of Biology, University of Opole, Oleska 48, 45-052 Opole, anowak@uni.opole.pl;

${ }^{7}$ Department of Plant Ecology and Environmental Protection, Faculty of Biology, Adam Mickiewicz University in Poznań, Umultowska 89, 61-614 Poznań, Poland, stanros@gmail.com;

${ }^{8}$ Institute of Biology, University of Szczecin, ul. Felczaka 3c, 71-412 Szczecin, Poland, agnieszka.popiela@usz.edu.pl.

*corresponding author 
31 Key words: syntaxonomical revision, distribution, Eleocharition, Verbenion, Radiolion

Abstract

So far, no formalized classification of the Isoëto-Nanojuncetea class has been carried out in Poland. The 69562 relevés stored in Polish Vegetation Database were used. On the basic of literature and expert knowledge the 63 diagnostic species for the Isoëto-Nanojuncetea class were selected. An unequivocal classification was applied in this work according to the Cocktail method. A set of formal definitions was established using a combination of logical operators of the total cover of species in case of high-rank syntaxa, while sociological species groups and cover of particular species were used for logical formulas describing class, alliances and associations. An Expert System was prepared and applied to classify the whole data set of PVD and 1340 relevés were organized at the class level. The data were stratified and finally data set of 903 relevés were used to prepare synoptic tables, distribution maps and descriptions of the syntaxa. In result, the 12 associations and two plant communities were identified. Vegetation of the Isoëto-Nanojuncetea class occurs in the central and southern part of Poland, with scattered stands in the northern region. Two new plant communities were described within Eleocharition and Radiolion alliances. The first formal classification of the Isoëto- Nanojuncetea class revealed a high diversity of ephemeral vegetation wetland found in Poland in the eastern boundary of their geographical distribution in Europe.

Introduction

The classification of plant communities in Poland is not fully conducted, although studies on vegetation have a long tradition (Matuszkiewicz 2007, Kącki, Czarnecka \& Swacha 2013). There are syntaxonomic units, due to seasonal dynamics, unique habitat requirements and species-poor layout, that have not been defined. Vegetation of the class Isoëto-Nanojuncetea is one example. These annual, pioneer ephemeral dwarf-cyperaceous vegetation, occurs in Central Europe in midfield hollows, at the bottoms of drying puddles, drained ponds, oxbows, lakes and rivers banks, in regularly flooded places, available for vegetation for a short period. Many species found on these locations are rare, although they usually have a wide distribution (Deil 2005, Lampe 1996). The communities of Isoëto-Nanojuncetea class in Europe were first identified and reported at the beginning of the 20th century (Koch 1926, Libbert 1932, Braun-Blanquet 1931, 1936). Later on, an essential contribution to the knowledge of diversity and classification of Isoëto-Nanojuncetea in Europe was provided by Moor (1936, 1937), Pietsch (1965, 1969, 1973), Pietsch \& Müller-Stoll (1968, 1974), Rivas Goday (1970), Tüxen (1973), Popiela (1997), Brullo \& Minissale (1998), Täuber (2000), Deil (2005, 2020) and Šumberová \& Hrivnák (2013).

The species diversity and communities`s structure of ephemeral vegetation often depend on the length of time of ground exposure or agricultural intensity and the soil seed bank (eg. Poschlod et al. 2013). At the initial development stage, an impoverishment in diagnostic species is often observed or the species are found in small patches among other annual vegetation, mostly of Bidentetea and Papaveretea classes. Additionally, some studies indicated that the same species are linked to different and distinctively defined plant associations. Hence, the classification of 
71 ephemeral wetland vegetation is confusing both on the level of associations and the whole class 72 (Popiela 2005, Šumberová \& Hrivnák 2013).

73 Plant communities of Isoëto-Nanojuncetea class in Poland reach out to the north-eastern 74 distribution boundaries, and most of these diagnostic species are rare and vanishing (Popiela 2005, 75 Kaźmierczakowa et al. 2016). For the first time in Poland, they were described by Kornaś (1960), 76 Wójcik (1968) and Zając \& Zając (1988). The first comprehensive classification based on large dataset was proposed by Popiela (1997). However, in recent decades, new regional studies on the syntaxonomy and ecology of Isoëto-Nanojuncetea vegetation have been published (e.g. Spałek \& Nowak 2006, Krawczyk et al. 2016). The new communities were identified and reported (Fabiszewski \& Cebrat 2003, Dajdok 2009). All this data are stored in national phytosociological database - Polish Vegetation Database (Kącki \& Śliwiński 2012). Large vegetation-plot databases are currently available worldwide (Dengler et al. 2011, Chytrý et al. 2016, Nowak et al. 2017), making possible a comprehensive classification of vegetation at different spatial scales (Dengler et al. 2013, De Cáceres \& Wiser 2012). To achieve consistency across large regions, the Cocktail method is adviced by Bruelheide $(1997,2000)$ to classify different vegetation types in Europe (e.g. Šilc \& Čarni 2007, Douda et al. 2016, Willner et al. 2019, Bruelheide et al. 2019). The formalized approach uses definitions, by which a particular relevé is classified into vegetation units in a reproducible way. Still, the classification results are independent of the origin of the data set (Bruelheide \& Chytrý 2000). The first attempt in the classification of Isoëto-Nanojuncetea vegetation by the use of Cocktail method was made by Šumberová \& Hrivnák (2013) for Czech and Slovakia territory. Authors have described formal definitions at the association level. In this study, we applied multilevel formalized classification (Janišová \& Dúbravková 2010), which was successfully introduced in classification of Molinia meadows in Poland (Swacha et al. 2016). This works aims to solve the inconsistencies in the Polish classification of ephemeral vegetation. We provide a formalized classification procedure and synthesis of Isoëto-Nanojuncetea class units for alliance and associations level. The classification considers the accepted and valid syntaxa described formerly in Europe as much as possible.

Material and Methods

Data set and classfication method

The 69562 relevés stored in Polish Vegetation Database PVD (Kącki \& Śliwiński 2012) were used for this study. Based on the literature and expert knowledge (Oberdorfer 1977, Popiela 1997, Matuszkiewicz 2007, Kącki et al. 2013), we selected 63 diagnostic species for the IsoëtoNanojuncetea class (Table 1). Then we defined groups of diagnostic species into class and alliances as reported from Central Europe (Matuszkiewicz 2007, Mucina et al. 2016). Using groups of species, we created functional species groups based on the total cover of all species (\#TC) separately for the class and alliances and functional species group with selection based on the highest cover of a single species (\#SC) according to Landucci et al. (2015) approach. Sociological groups of species were simultaneously determined using the fidelity phi coefficient (Chytrý et al. 2002). We applied unequivocal classification in accordance with Cocktail method (Bruelheide 1997). Formulas were created using the formal operators AND, OR, NOT available in Juice 
112 software (Tichý 2002). The structure of the formulas for alliance level based on total cover groups 113 \#TC and cover of a single species \#SC, while the association level was created by a combination 114 of sociological species groups or a cover threshold of particular diagnostic species associated with 115 the alliance's total cover group, enabling us to keep the syntaxonomical hierarchy, which means 116 that relevés classified to a particular association were also included into the appropriate alliance

117

118

119

120

121

122

123

124

125

126

127

128

129

130

131

132

133

134

135

136

137

138

139

140

141

142

143

144

145

146

147

148

149 and the class (Landucci et al. 2020, Kącki et al. 2020). An Expert System was prepared and applied to classify the whole data set of PVD and 1340 relevés were organized at the class level. Relevés without geographical coordinates and a surface area smaller than $1 \mathrm{~m}^{2}$ or greater than $100 \mathrm{~m}^{2}$ were excluded. We also removed cultivated plants from the analyses. Next, three relevés were randomly selected from each unit of grid square of 1.25 longitude x 0.75 latitude (ca. $1.5 \times 1.4 \mathrm{~km}$ ) from each vegetation units distinguished. Finally, we used data set of 903 relevés to prepare synthetic tables, distribution maps and descriptions of the syntaxa. For each syntaxon diagnosic, differential, constant and dominant species were determined and a combined synoptic table with percentage frequency and fidelity was created. Additionally, the statistical significance of the fidelity was calculated using Fisher's exact test (Sokal \& Rohlf 1995, Chytrý et al. 2002). We considered as a diagnostic only species which were included in the list of preselected 63 species for IsoëtoNanojunceta class, while the others we indicated as differential species. Species were considered as diagnostic or differential for the alliances at $\mathrm{phi} \geq 0.20$ and for the association at $\mathrm{phi} \geq 0.25$ and Fisher's exact test at significance level of $\mathrm{p}<0.001$. Constant and dominant species were those with a frequency of $\geq 40 \%$ and with a cover value at least $25 \%$ in at least $5 \%$ of relevés of paricular vegetation units, respectively. We used Euro-Med-Plant + nomenclature for species names (access 11.2018). Taxonomically critical taxa were merged into aggregates.

Statistics, map preparation, nomeclature

Ecological gradients of defined associations were evaluated by Detrended Correspondence Analysis (DCA) using Juice 7.1.28 and ordination methods available in R for Windows with VEGAN module (Oksanen et al. 2011). For interpretation of the main environmental gradients, average non-weighted Ellenberg indicator values for light, temperature, continentality, soil reaction, moisture and nutrients (Ellenberg et al. 1992) were used as supplementary variables. Ellenberg indicator values were calculated for weighted relevés by species cover (CWM). The ordination (DCA) was conducted with data transformation $\mathrm{b}=(\mathrm{Xi}, \mathrm{j})^{\wedge} \mathrm{p}(\mathrm{p}=0.5)$ and scaling by 26 segments. Distribution maps of all associations were prepared using PostgreSQL 11.0 database with PostGIS 2.6 extension. Visualisation of the result was prepared on QGIS3.16.3 and results showed on digital elevation map with accuracy $100 \times 100 \mathrm{~m}$ by pixel. .

Table 1.

Results

Three alliances with 14 plant communities were identified in Poland (Tab. 2). 541 relevés were assigned to associations (60\% of 903 relevés used) and 197 relevés were classified at the class 
150 level and 157 at the alliances level only (Tab. 2). We identified 12 plant associations and a 151 community with Coleanthus subtilis placed into the Eleocharition soloniensis alliance, and a 152 community with Montia arvensis included into the Radiolion linoidis alliance. According to DCA 153 analysis based on the Ellenberg Indicator Values, the most influential factors determining the 154 species composition are moisture and temperature (Fig.1).

155 Communities of the Isoëto-Nanojuncetea class occur in the central and southern parts of Poland, 156 so far they were not found in north-eastern Poland and are rarely found in northern parts (Fig. 2).

157 Localities of the Eleocharition soloniensis stands are distributed mainly in the western and south158 eastern part of Poland in big river valleys and fishpond regions (Fig. 3A). The Verbenion supinae 159 communities are the rarest, sparsely distributed in Poland's midlle part, mostly in the Lubelska 160 Upland and the Wielkopolska Lowland (Fig. 3B). Localities of Radiolion linoidis alliance are 161 distributed mainly in the central and the south-eastern part of Poland (Fig. 3C).

162

163

164

165

166

167

168

169

170

171

172

173

174

175

176

177

178

179

180

181

182

183

184

185

186

187

188

189

190

191

Table 2.

Figure 1.

Figure 2.

Figure 3.

\section{List of syntaxa and species composition}

Eleocharition soloniensis Philippi 1968

Diagnostic species: Eleocharis acicularis, Cyperus fuscus, Limosella aquatica, Eleocharis ovata, Carex bohemica, Elatine hexandra, Elatine hydropiper, Riccia cavernosa, Elatine triandra

Differential species: Callitriche palustris s. l., Alisma plantago-aquatica, Rorippa palustris, Leersia oryzoides, Juncus articulatus, Alopecurus geniculatus, Ranunculus sceleratus, Juncus bulbosus, Physcomitrium eurystomum Constant species: Cyperus fuscus, Limosella aquatica, Gnaphalium uliginosum, Eleocharis acicularis, Rorippa palustris

Dominant species: Cyperus fuscus, Eleocharis acicularis, Eleocharis ovata, Limosella aquatica, Elatine hexandra

In Poland, the Eleocharition soloniensis alliance comprises four plant communities (Appendix 2, 3):

1. Polygono-Eleocharitetum ovatae Eggler 1933

2. Cypero fusci-Limoselletum aquaticae Oberd. ex Korneck 1960

3. Cyperetum micheliani Horvatić 1931

4. Community with Coleanthus subtilis

They develop on moderately fertile habitats, mainly on the drying-out bottom of fishponds, the margins of mid-field ponds, and periodically exposed banks of river channels, mostly in Poland`s western part. (Fig. 4). According to DCA analysis, based on the Ellenberg Indicator Values, moisture, nutrients, and temperature differ the vegetation of the Eleocharition alliance (Fig. 5).

Figure 4 .

Peer] reviewing PDF | (2020:11:55719:2:1:NEW 23 May 2021) 
192 Polygono-Eleocharitetum ovatae Eggler 1933

193 Diagnostic species: Eleocharis ovata, Carex bohemica, Elatine hexandra, Eleocharis acicularis, Elatine triandra,

194 Lindernia procumbens

195 Differential species: Alisma plantago-aquatica, Juncus bulbosus, Physcomitrium eurystomum, Oenanthe aquatica,

196 Scirpus radicans

197 Constant species: Eleocharis ovata, Eleocharis acicularis, Alisma plantago-aquatica,

198

199

200

201

202

203

204

205

206

207

208

209

210

211

212

213

214

215

216

217

218

219

220

221

222

223

224

225

226

227

228

229

230

231

232

233

234

235

236

237

238

239

240

241

Dominant species: Eleocharis ovata, Elatine hexandra, Eleocharis acicularis, Carex bohemica, Juncus bulbosus

Distribution: Polygono-Eleocharetum ovatae occurs on scattered sites in the south-western and south-eastern parts of Poland. It does not occur in the north of the country due to scarcity of typical habitat - the fishpond complexes (Fig. 4).

Physiognomical layout: The individual patches show a single-layer structure and form a low turflike vegetation, with varying coverage. The association often develops patchy structure, with typical plots composed of diagnostic species dispersed between stands of PhragmitoMagnocaricetea and Bidentetea vegetation (Fig. 5).

Habitat requirements: The Polygono-Eleocharitetum ovatae is associated with ponds habitats (old facilities) ), with regular, extensive fishery management for a long time. It does not appear on natural water bodies across Poland. It is mostly found on a fine-grained, wet, moist or drying sandy-loamy or silty substrate, rich in mineral compounds. Within the Eleocharition alliance this association is usually the most waterlogged one habitat (Fig. 6).

Figure 5 .

\section{Cypero fusci-Limoselletum aquaticae Oberd. ex Korneck 1960}

Diagnostic species: Cyperus fuscus, Limosella aquatica, Eleocharis acicularis

Differential species: Salix purpurea, Plagiochila asplenioides

Constant species: Cyperus fuscus, Limosella aquatica, Gnaphalium uliginosum, Plantago major subsp. intermedia, Juncus bufonius, Rorippa palustris, Rumex maritimus

Dominant species: Cyperus fuscus, Limosella aquatica, Plantago major subsp. intermedia, Eleocharis acicularis

Distribution: The Cypero fusci-Limoselletum aquaticae occurs mostly in the western part of Poland on natural sites along river valleys of Odra, Warta and lower part of Vistula while rarely is found on fishpond's complexes (Fig. 4).

Physiognomical layout: The association develops compact turf, usually at late summer. It is distinguished by the abundant occurrence of Cyperus fuscus (Fig. 5).

Habitat requirements: In Poland, patches of the Cypero fusci-Limoselletum aquaticae develop periodically on flooded habitats, located on gently sloping banks, coastal mudslides, margins of oxbow lakes and small water-filled hollows on the flooded terraces. They are also found on the freshly exposed bottom of water reservoirs, e.g. lakes, small mid-field depressions, at the bottoms of drained fishponds and dam reservoirs. This association has the highest requirements regarding nutrients and have less demand for moisture within the whole alliance' communities (Fig. 6).

\section{Cyperetum micheliani Horvatić 1931}

Diagnostic species: Cyperus michelianus

Constant species: Rumex maritimus, Plantago major subsp. intermedia, Gnaphalium uliginosum, Cyperus michelianus, Cyperus fuscus, Rorippa palustris, Oxybasis rubra, Cirsium arvense, Salix fragilis, Rorippa amphibia, Lythrum salicaria, Limosella aquatica, Erigeron canadensis, Bidens frondosus, Atriplex prostrata, Agrostis stolonifera

Dominant species: Cyperus michelianus, Cyperus fuscus

Peer) reviewing PDF | (2020:11:55719:2:1:NEW 23 May 2021) 
254

255

256

257

258

259

260

261

262

263

264

265

266

267

268

269

270

271

272

273

274

275

276

277

278

279

280

281

282

283

284

285

286

287

288

289

290

291

Distribution: The Cyperetum micheliani was found on single locality in south-western part of Poland, in the Odra river valley near Głogów (Fig. 4).

Physiognomical layout: The association develops compact turf and and is distinguished by the dominance of Cyperus michelianus (Fig. 5).

Habitat requirements: In Poland, patches of the Cyperetum micheliani develop on margins of oxbow lakes and on the flooded terraces of the riverbanks. The association has highest requirements regarding nutrients and has less demand for moisture within the Eleocharition alliance (Fig. 6).

Figure 6.

\section{Community with Coleanthus sublitis}

Diagnostic species: Coleanthus subtilis, Veronica peregrina, Riccia cavernosa,

Myosurus minimus, Limosella aquatica

Differential species: Ranunculus trichophyllus, Callitriche palustris s. l., Persicaria lapathifolia s. l.

Constant species: Coleanthus subtilis, Veronica peregrina, Myosurus minimus, Limosella aquatica, Persicaria

lapathifolia s. l., Rorippa palustris, Callitriche palustris s. l., Persicaria hydropiper, Juncus bufonius, Riccia cavernosa, Ranunculus trichophyllus

Dominant species: Coleanthus subtilis, Veronica peregrina, Myosurus minimus, Riccia cavernosa, Persicaria lapathifolia s. l., Limosella aquatica, Callitriche palustris s. l., Ranunculus trichophyllus

Distribution: So far, the community was found only in the south-western part of Poland, in fishpond complexes in Lower Silesia (Fig. 4).

Physiognomical layout: The community is well distinguished by the dominance of short grasses mostly the diagnostic species Coleanthus subtilis (Fig. 5).

Habitat requirements: Preferably, plots of is this community develop in ponds used in annual or biennial cycle (stocking ponds). So far, this plant communities developing in autumn or during seasonal summer water deficit have been recorded much less frequently.

\section{Verbenion supinae Slavnić 1951}

Diagnostic species: Pulicaria vulgaris, Cyperus flavescens, Elatine alsinastrum, Schoenoplectus supinus, Lythrum hyssopifolia

Differential species: Agrostis stolonifera, Alisma lanceolatum, Atriplex prostrata, Argentina anserina, Xanthium orientale subsp. italicum, Inula britannica, Cynosurus cristatus, Salix triandra, Poa pratensis

Constant species: Agrostis stolonifera, Plantago major subsp. intermedia

Dominant species: Pulicaria vulgaris, Elatine alsinastrum, Schoenoplectus supinus, Juncus bufonius, Cyperus flavescens, Plantago major subsp. intermedia, Alisma lanceolatum

According to the formal classification of our data set, the Verbenion supinae alliance includes four associations (Appendix 2, 3):

1. Veronico anagalloidis-Lythretum hyssopifoliae Wagner ex Holzner 1973

2. Cyperetum flavescentis Koch 1926

3. Pulicario vulgaris-Menthetum pulegii Slavnić 1951

4. Eleocharito-Schoenoplectetum supini Soo \& Ubrizsy 1948 (orig. Schoenoplectus supinusHeleocharis acicularis assz.) 
292 In Poland, vegetation of this alliance occurs rarely, mainly in the big river valleys and in the Lublin 293 Upland (Fig. 3). According to DCA analysis based on the Ellenberg Indicator Values, Poland`s 294 Verbenion supinae alliance has high demand of the temperature and nutrient content (Fig. 7).

295

296

297

298

299

300

301

302

303

304

305

306

307

308

\title{
Figure 7.
}

\author{
Veronico anagalloidis-Lythretum hyssopifoliae Wagner ex Holzner 1973 \\ Diagnostic species: Juncus ranarius \\ Constant species: Juncus ranarius, Oxybasis rubra, Oxybasis glauca, Juncus compressus, Atriplex prostrata, \\ Argentina anserina, Agrostis stolonifera \\ Dominant species: Juncus ranarius, Carex secalina, Bolboschoenus maritimus agg.
}

Distribution: There are only three known sites of the Veronico anagalloidis-Lythretum hyssopifoliae in Poland located in the lowland belt of Wielkopolska, Kujawy and Mazury regions (Fig. 8).

Physiognomical layout: The association is well defined by Juncus ranarius and the presence of halophilous species.

Habitat requirements: The association occurs on saline, moist silts, and wet soils in nutrient rich habitats.

\section{Cyperetum flavescentis Koch 1926}

Diagnostic species: Cyperus flavescens, Sagina nodosa

Differential species: Calliergonella cuspidata, Triglochin palustris, Ranunculus flammula

Constant species: Cyperus flavescens, Sagina nodosa, Ranunculus flammula, Juncus articulatus, Calliergonella cuspidata, Agrostis stolonifera

Dominant species: Cyperus flavescens

Distribution: The Cyperetum flavescentis is distributed in the south-eastern part of Poland (Fig. 8).

Physiognomical layout: It forms very low and sparsy turfs on a sandy or sandy-loam substrates with weak acidity. The plant communities are usually clearly dominated by Cyperus flavescens (Fig. 9).

Habitat requirements: The communities develop periodically on flooded and grazed lakesides as well as peaty hollows. According to DCA analysis Cyperetum flavescentis requires lower humidity and nutrients content than other associations of the Verbenion alliance (Fig. 7).

Figure 8.

\footnotetext{
Pulicario vulgaris-Menthetum pulegii Slavnić 1951

Diagnostic species: Pulicaria vulgaris

Differential species: Xanthium orientale subsp. italicum, Inula britannica, Lysimachia nummularia, Matricaria discoidea, Poa pratensis, Cynosurus cristatus, Agrostis stolonifera

Constant species: Pulicaria vulgaris, Agrostis stolonifera, Plantago major subsp. intermedia, Persicaria hydropiper, Juncus bufonius, Gnaphalium uliginosum, Persicaria lapathifolia s. l., Rumex maritimus, Argentina anserina, Bidens tripartitus

Dominant species: Pulicaria vulgaris, Juncus bufonius, Plantago major subsp. intermedia, Eleocharis acicularis, Mentha pulegium, Lysimachia nummularia
} 
Distribution: In Poland, the association occurs on scattered sites, mainly in the valleys of Odra and Warta rivers (Fig. 8).

Physiognomical layout: It is a community found mostly in the flood zone of big rivers. In addition to the dominating diagnostic species, an essential contribution to this vegetation are species from the Bidentetea class.

Habitat requirements: The association reveals relatively high nutrients demand (Fig. 7).

\section{Eleocharito-Schoenoplectetum supini Soo \& Ubrizsy 1948 nomina inversa prop. (orig. Schoenoplectus supinus-Heleocharis acicularis assz.)}

Diagnostic species: Elatine alsinastrum, Schoenoplectus supinus, Lythrum hyssopifolia

Differential species: Alisma lanceolatum, Persicaria amphibia

Constant species: Alisma lanceolatum, Elatine alsinastrum, Schoenoplectus supinus, Limosella aquatica

Dominant species: Elatine alsinastrum, Schoenoplectus supinus, Alisma lanceolatum, Plantago major subsp. intermedia, Lythrum portula, Juncus bufonius

Distribution: Eleocharito-Schoenoplectetum supini is scattered in Poland. The majority of records come from the Lublin region's uplands, but it was also sporadically found in northwestern Poland (Fig. 8).

Physiognomical layout: In the initial phase, it is a distinguished pioneer vegetation type and was encountered in both the terrestrial and aquatic habitats. Its optimal phase is characterized by a high cover and relatively height (up to half a meter) (Fig. 9).

Habitat requirements: The association develops most often in temporary pools in arable field depression (some of them occur episodically during periods with abundant precipitation). The association is the most demanding considering moisture and temperature within the Verbenion supinae alliance (Fig. 7).

Figure 9.

\section{Radiolion linoidis Pietsch 1973}

Diagnostic species: Hypericum humifusum, Radiola linoides, Gypsophila muralis, Anagallis minima, Anthoceros punctatus s. l., Spergularia rubra, Juncus capitatus, Illecebrum verticillatum, Phaeoceros laevis, Gnaphalium uliginosum, Riccia glauca, Isolepis setacea, Riccia sorocarpa, Fossombronia wondraczekii, Montia arvensis

Differential species: Spergula arvensis, Rumex acetosella, Scleranthus annuus, Equisetum arvense, Sagina procumbens, Setaria pumila, Elytrigia repens, Viola arvensis, Fallopia convolvulus, Polygonum aviculare s. l., Mentha arvensis, Stellaria media s. l., Veronica arvensis, Juncus bufonius, Achillea millefolium, Veronica serpyllifolia, Erigeron canadensis, Anthemis arvensis, Raphanus raphanistrum, Anagallis arvensis, Myosotis arvensis, Cyanus segetum, Cerastium fontanum subsp. vulgare, Cirsium arvense, Apera spica-venti, Teesdalia nudicaulis, Stachys palustris, Vicia sativa s. l., Oxalis fontana, Arnoseris minima, Vicia hirsuta, Convolvulus arvensis, Galeopsis tetrahit s. l., Capsella bursa-pastoris, Holcus mollis, Ceratodon purpureus, Erodium cicutarium, Digitaria ischaemum, Agrostis capillaris, Bryum argenteum, Setaria viridis, Vicia tetrasperma, Veronica persica, Ranunculus repens, Pohlia nutans, Sonchus arvensis

Constant species: Juncus bufonius, Gnaphalium uliginosum, Rumex acetosella, Polygonum aviculare s. l., Plantago major subsp. intermedia, Sagina procumbens, Hypericum humifusum, Radiola linoides, Gypsophila muralis, Spergula arvensis, Anagallis minima, Spergularia rubra, Scleranthus annuus, Equisetum arvense

Dominant species: Juncus bufonius, Isolepis setacea

There are six associations of the Radiolion linoidis in Poland distiguished by a formal classification 
(Appendix 2, 3):

1. Stellario uliginosae-Isolepidetum setaceae Libbert 1932

2. Centunculo minimi-Anthoceretum punctati Koch ex Libbert 1932

3. Hyperico humifusi-Spergularietum rubrae Wójcik 1968

4. Panico-Illecebretum verticillati Diemont \& al. 1940

5. Cerastio dubii-Ranunculetum sardoi Oberdorfer ex Vicherek

6. Community with Montia arvensis

According to DCA analysis based on the Ellenberg Indicator Values, the Radiolion linoidis alliance communities are differentiated by habitat requirements in terms of moisture, light, nutrients, and soil reaction.

\section{Stellario uliginosae-Isolepidetum setaceae Libbert 1932}

Diagnostic species: Isolepis setacea

Differential species: Stellaria alsine, Juncus articulatus, Leontodon saxatilis, Calamagrostis epigejos, Juncus effusus, Carex flava agg.

Constant species: Isolepis setacea, Juncus articulatus, Juncus bufonius, Gnaphalium uliginosum, Stellaria alsine, Sagina procumbens, Plantago major subsp. intermedia

Dominant species: Isolepis setacea, Juncus bufonius

Distribution: Stellario uliginosae-Isolepidetum setaceae rarely occurs in Poland, mostly in the river valleys in its western part (Fig. 10).

Physiognomical layout: It occurs in the form of low turf with varying degrees of vegetation cover. The communities have a considerable number of diagnostic species of the MolinioArrhenatheretea and the Scheuchzerio-Caricetea vegetation (Fig. 11).

Habitat requirements: This plant community was recorded on extensively used forest roads, as well as mid-field depressions and pond margins. According to DCA results, Stellario uliginosaeIsolepidetum setaceae has higher demand of moisture and lower soils reaction requirements than other communities of the Radiolion alliance (Fig. 12).

Figure 10.

\section{Centunculo minimi-Anthoceretum punctati Koch ex Libbert 1932}

Diagnostic species: Anagallis minima, Anthoceros punctatus s. l., Radiola linoides, Juncus capitatus, Phaeoceros laevis,

Differential species: Rumex acetosella

Constant species: Anagallis minima, Juncus bufonius, Radiola linoides, Gnaphalium uliginosum, Anthoceros punctatus s. l., Polygonum aviculare s. l., Sagina procumbens, Plantago major subsp. intermedia, Juncus capitatus, Rumex acetosella, Gypsophila muralis, Equisetum arvense, Spergula arvensis, Hypericum humifusum Dominant species: Juncus bufonius, Anthoceros punctatus s. l. l.

Distribution: The Centunculo minimi-Anthoceretum punctati occurs mostly in the south-eastern part of the country: the Masovian Plain, the Małopolska Upland, the Podlasie Lowland and the Beskid Foothills. Additionally, a single site was noted in the western Poland - Fig. 10.

Physiognomical layout: The communities are characterized by small annual vascular plants and significant share of bryophytes (Fig. 11). 
441 Habitat requirements: The community develops on arable fields, in the second half of summer and early autumn. A necessary condition for its development is the presence of an exposed and moist substrate. In such places, rainwater stays longer, and there are no dense high weeds stands. These are furrows and mid-field depressions, drying edges of puddle margins, wet spots on clay or sandy, slightly acidic soil. This association has lower moisture and higher temperature demand within the Radiolion alliance (Fig. 12).

Figure 11.

Figure 12.

\section{Hyperico humifusi-Spergularietum rubrae Wójcik 1968}

Diagnostic species: Spergularia rubra, Gypsophila muralis, Hypericum humifusum, Anagallis minima, Anthoceros punctatus s. l., Laphangium luteoalbum,

Differential species: Scleranthus annuus, Convolvulus arvensis, Veronica serpyllifolia, Anthemis arvensis, Rumex acetosella, Elytrigia repens, Sagina procumbens, Oxalis fontana, Anagallis arvensis, Setaria pumila, Polygonum aviculare s. l., Myosotis arvensis, Raphanus raphanistrum, Erigeron canadensis, Viola arvensis, Crepis tectorum, Spergula arvensis

Constant species: Spergularia rubra, Gypsophila muralis, Juncus bufonius, Gnaphalium uliginosum, Sagina procumbens, Polygonum aviculare s. l., Scleranthus annuus, Plantago major subsp. intermedia, Rumex acetosella, Hypericum humifusum, Anagallis minima, Elytrigia repens, Veronica serpyllifolia, Setaria pumila, Erigeron canadensis, Spergula arvensis, Anthemis arvensis, Equisetum arvense, Viola arvensis

Dominant species: Juncus bufonius, Rumex acetosella

Distribution: The Hyperico humifusi-Spergularietum rubrae occurs in the south-eastern part of Poland (Fig. 10).

Physiognomical layout: The association dominated by small annual vascular plants, mostly diagnostic for Radiolion alliance with considerable constancy and also has species diagnostic for Papaveretea vegetation (Fig. 11).

Habitat requirements: The Hyperico humifusi-Spergularietum rubrae occurs in conditions very similar to Centunculo minimi-Anthocetetum punctati and it is found in wet depression in arable fields and in vicinity of mid-field water reservoirs. Likewise, DCA analysis results showed similarity in habitat demand as Centunculo minimi-Anthoceretum punctati (Fig. 12).

\section{Panico-Illecebretum verticillati Diemont \& al. 1940}

Diagnostic species: Illecebrum verticillatum, Spergularia rubra, Hypericum humifusum, Radiola linoides

Differential species: Teesdalia nudicaulis, Arnoseris minima, Spergula arvensis, Scleranthus annuus, Holcus mollis, Rumex acetosella, Digitaria ischaemum, Raphanus raphanistrum, Setaria pumila, Fallopia convolvulus, Aphanes microcarpa, Anthoxanthum aristatum, Galeopsis tetrahit s. l., Rhinanthus angustifolius, Bidens tripartitus, Setaria viridis, Stachys palustris, Persicaria hydropiper, Mentha arvensis, Viola tricolor agg., Myosotis arvensis, Achillea millefolium

Constant species: Illecebrum verticillatum, Spergula arvensis, Rumex acetosella, Juncus bufonius, Spergularia rubra, Scleranthus annuus, Persicaria hydropiper, Hypericum humifusum, Gnaphalium uliginosum, Radiola linoides, Mentha arvensis, Setaria pumila, Teesdalia nudicaulis, Bidens tripartitus, Arnoseris minima, Polygonum aviculare s. l., Equisetum arvense, Fallopia convolvulus, Raphanus raphanistrum, Agrostis stolonifera

Dominant species: Illecebrum verticillatum

Distribution: Panico-Illecebretum verticillati occurs in the south-eastern part of Poland (Fig. 10) similary to Centunculo minimi-Anthocetetum punctati and Hyperico humifusi-Spergularietum rubrae.

Physiognomical layout: It develops at the end of summer, in the form of small patches, on moist soil in crop stands or on stubble. Compared to Centunculo-Anthoceretum, it differs in its abundant 
occurrence of Illecebrum verticillatum and Spergula arvensis and others sandy, acidophilous plants with the negligible amount of bryophytes.

Habitat requirements: The soil is more acidic; according to DCA, it also has lower humidity and higher temperature requirements (Fig. 12).

\section{Cerastio dubii-Ranunculetum sardoi Oberdorfer ex Vicherek 1968}

Diagnostic species: Ranunculus sardous, Myosurus minimus, Plantago major subsp. intermedia

Differential species: Capsella bursa-pastoris, Bryum dichotomum, Bryum caespiticium, Bryum ruderale, Papaver rhoeas, Linaria spartea, Galium aparine, Dicranella varia, Thlaspi arvense, Veronica persica, Barbula unguiculata, Veronica hederifolia, Erodium cicutarium, Valerianella locusta, Tortula modica, Phascum cuspidatum, Brachythecium rutabulum, Geranium pusillum, Ceratodon purpureus, Stellaria media s. l., Marchantia polymorpha, Leptobryum pyriforme, Vicia hirsuta, Tripleurospermum inodorum agg.

Constant species: Ranunculus sardous, Plantago major subsp. intermedia, Myosurus minimus, Juncus bufonius, Gnaphalium uliginosum, Capsella bursa-pastoris, Stellaria media s. l., Ceratodon purpureus, Bryum dichotomum, Bryum caespiticium, Tripleurospermum inodorum agg., Dicranella varia, Bryum ruderale, Viola arvensis, Vicia hirsuta, Veronica persica, Thlaspi arvense, Sagina procumbens, Riccia glauca, Polygonum aviculare s. l., Mentha arvensis, Leptobryum pyriforme, Galium aparine, Erodium cicutarium, Bryum argenteum, Brachythecium rutabulum Dominant species: Ranunculus sardous, Myosurus minimus, Riccia glauca, Lythrum portula, Juncus bufonius, Gnaphalium uliginosum

Distribution: The association found on scattered localities mainly in river valleys across Poland (Fig. 10).

Physiognomical layout: The patches of the association develop in early summer - mainly in June and July. The number of species from the Isoëto-Nanojuncetea class is insignificant, and plants of the Papaveretea class are considerable contributors (Fig. 11).

Habitat requirements: It occurs in damp places in mid-field furrows, on fallow fields and their margins. It is a short-term seasonal community, composed exclusively of annuals. Analysis of Ellenberg indicator values showed that Cerastio dubii-Ranunculetum sardoi has a higher demand for moisture and nutrient content (Fig. 12).

\section{Community with Montia arvensis}

Diagnostic species: Montia arvensis, Myosurus minimus, Riccia sorocarpa

Differential species: Dicranella staphylina, Holcus lanatus, Epilobium ciliatum, Lotus pedunculatus, Bryum subapiculatum, Lathyrus pratensis, Bryum violaceum, Lysimachia vulgaris, Myosotis discolor, Pohlia annotina, Poa trivialis, Arabidopsis thaliana, Cerastium glomeratum, Eupatorium cannabinum, Vicia hirsuta, Solidago gigantea, Rumex crispus, Lamium purpureum, Bidens frondosus, Veronica arvensis, Ranunculus repens, Stellaria palustris, Pleuridium acuminatum, Glyceria declinata, Galium palustre agg., Tripleurospermum inodorum agg., Leptobryum pyriforme, Ceratodon purpureus

Constant species: Montia arvensis, Juncus bufonius, Myosurus minimus, Lotus pedunculatus, Holcus lanatus, Vicia hirsuta, Tripleurospermum inodorum agg., Ranunculus repens, Gnaphalium uliginosum, Epilobium ciliatum, Dicranella staphylina, Bidens frondosus, Agrostis stolonifera, Veronica arvensis, Rorippa palustris, Persicaria hydropiper, Lysimachia vulgaris, Polygonum aviculare s. l., Poa trivialis, Plantago major subsp. intermedia, Persicaria lapathifolia s. l., Mentha arvensis, Ceratodon purpureus, Bryum subapiculatum

Dominant species: Montia arvensis, Juncus bufonius, Pohlia annotina, Argentina anserina

Distribution: This community was recorded in western Poland in the Lubuskie Region only (Fig. 10).

Physiognomical layout: Montia arvensis is mostly accompanied by Myosurus minimus and common segetal weeds of the Papaveretea class (Fig. 11). 
543 Habitat requirements: Community with Montia arvensis was found in moist, sandy arable fields. 544 It develops mostly near backwaters after spring thaws, on silts, in drainage ditches and spring 545 outflows. Less frequently it was found in fallows and wastelands. According to DCA, the

\section{Discussion}

The distribution of the stands of Isoëto-Nanojuncetea class in Poland reflects the following patterns: they are quite common in the central and southern part of Poland, rarely found in the east and central Pomerania and absent in Warmia and Mazury regions. This is because 25 (65.7\%) characteristic taxa of the class extended to the eastern distribution boundary of their European range (Popiela 2005). Moreover, a large part of these communities in Poland has no characteristic feature and could be classified into alliances only.

In accordance with the syntaxonomic concept of Mucina et al. (2016), the order Nanocyperetalia Klika 1935 includes six alliances, of which three occur in Central Europe: Eleocharition soloniensis Philippi 1968, Verbenion supinae Slavnić 1951 and Radiolion linoidis Pietsch 1973. All occur in Poland (Kącki, Czarnecka \& Swacha 2013). Two alliances are the most widespread the Eleocharition soloniensis (53.3\% of relevés fall into this alliance) and the Radiolion linoidis (39.3\% relevés). The Verbenion supinae vegetation represents only $7.3 \%$ of the relevés set. Our results showed that vegetation of Radiolion is likely more frequent in Poland than in the southern part of Europe, especially in the Czech Republic and Slovakia (Šumberová \& Hrivnák 2013). The Radiolion linoidis is mostly distributed in the Atlantic zone of Europe and additionally in damp habitats of heaths (Moor 1936, Pietsch 1973). Habitats of this vegetation are to highest extend, exclusively moistened by precipitation occasionally by floodings, as reported by Pietsch (1973). According to Deil (2005) and Šumberová \& Hrivnák (2013), high amount of precipitation before growing season is crucial for the development its characteristic species and the vegetation itself. Our results showed that the Radiolion communities require less humidity compared to the other two alliances. In the eastern and central parts of Poland the vegetation of Radiolion alliance is more common (traditional, familly farming system prevails there). It rarely occurs in the northern and western part of the country, where formerly socialized agriculture prevailed (Sikora 2012). In most of vegetation's overviews of Central European the Verbenion supinae vegetation was not reported (Oberdorfer 1998, Täuber \& Petersen 2000, Matuszkiewicz 2007), however has recently been indicated in Czech Republik and Slovakia (Šumberová \& Hrivnák 2013).

A limited number of diagnostic species of Verbenion supinae alliance found in Poland. Its occurrence was uncertain so far (Popiela 1997). It is not clear the relation between Verbenion supinae and Nanocyperion in Europe. The vegetation of Verbenion was considered as Mediterranean and subcontinental, sub-halo-nitrophilic communities and Nanocyperion as EuroSiberian vegetation on acidophilous to neutrophilous soils (Deil 2005, Biondi at al. 2014). On the other hand Verbenion is considered as the vegetation of nemoral zone of Central and southeastern Europe while Nanocyperion of the submediterranean and Atlantic regions of Europe (Mucina at al. 2016). We followed Mucina at al. (2016) concept of the class Isoëto-Nanojuncetea, although the Verbenion supinae alliance in Poland is strongly impoverished.

Altogether, 14 assemblages were distinguished using the formal definition in Poland. The most widespread are associations Polygono-Eleocharitetum ovatae and Cypero-Limoselletum. This also corresponds with the observations from other European countries (e.g. Philippi 1977, Müller-Stoll \& Pietsch 1985, Bagi 1988, Täuber 2000, Šumberová \& Hrivnák 2013). We described Cypero- 
589 Limoselletum which was included as synonym into association Cyperetum micheliani (Šumberová 2011a). In Poland Cyperus michelianus is very rare sub-mediterranean species occurring on the north limits of its geographical range. We distinguished this association based on relevés from the single locality in Poland. Following Horvatićs (1931) concept plots with dominance of Cyperus michelianus were included only. Most common in Poland is the Cypero-Limoselletum association described after Oberdorfer by Korneck (1960). It is well defined pionier vegetation mostly on natural habitats along big rivers banks in western part of the country. Cypero-Limoselletum is widespread in Europe and Asia (e.g. Pietsch 1973, Rašomavičius \& Biveinis 1996, de Foucault 2013, Dubyna et al. 2015, Taran 2019), it was also classified as a community Cyperus fuscusLimosella aquatica (Popiela 1997). Cypero-Limoselletum is vell separated vegetation units of cypetroids, rarely enriched (especially of exposed pond bottoms) by diagnostic species of Polygono-Eleocharitetum. Among the Eleocharition alliance we also described a community with Coleanthus subtilis which recently found in Poland (Fabiszewski \& Cebrat 2003). It occurs preferably in ponds used in the annual or biennial cycle (stocking ponds), with emptying in late autumn and filling at the turn of April and May. The habitat conditions of plant communities with Coleanthus subtilis showed that it develops on organic soils with a $\mathrm{pH}$ of $6.4-7.8$, rich in $\mathrm{N}, \mathrm{K}$, $\mathrm{Mg}, \mathrm{Ca}$ and $\mathrm{Na}$, and low in $\mathrm{P}$ (Dajdok et al. 2017). In Europe, there is no uniform approach to the classification of patches with Coleanthus subtilis. They were included in PolygonoEleocharitetum, Cyperetum micheliani and Stellario uliginosae-Isolepidetum setaceae (Pietsch 1973, Brullo \& Minissale 1998, Šumberová \& Hrivnák 2013, Richert et al. 2016).

Communities of Verbenion supinae alliance require higher contents of calcium and soluble mineral salts in the substrate (Pietsch 1973). They were rarely reported from Poland. The Pulicario vulgaris-Menthetum pulegii was documented mainly by Strech (1941) and Borysiak (1994) and included into Bidentetea class. According to our results, relevés with high number of annuals of Isoëto-Nanojuncetea class are classified to this unit. Veronico anagalloidis-Lythretum hyssopifoliae still poorly recognized in Poland, probably has a transitional character to halophitic communities of the Festuco-Puccinellietea class and requires further research.

Cyperetum flavescentis is classified differently in the phytosociological literature (Moor 1936, Pietsch 1973, Pietsch \& Müller-Stoll 1974). Due to data scarcity, Popiela (1997) temporarily included this association into the alliance Eleocharition soloniensis. Cyperetum flavescentis was rarely found in Poland. However, new findings of large populations of Cyperus flavescens have recently been reported from the south and north-eastern parts of Poland (Marciniuk et al. 2020). Habitats of this species are periodically wet, and soil are alkaline or slightly acidic. More frequent warm summers with a heavy rainfall in Poland enhance the population of this species (Marciniuk et al. 2020). The authors suggested that geographical range of Cyperus flavescens in Europe will increase because of global warming. In Central Europe Cyperetum flavescentis was rarely recorded in until now (Pietsch 1973, Pietsch \& Müller-Stoll 1974, Popiela 1997). It is therefore poorly represented in our dataset but it is clearly distinguishable by the dominance of Cyperus flavescens and accompanying species, mostly marsh and meadows species. Currently increasing population in Poland is crucial for its preservation in Central Europe (Marciniuk et al. 2020). It is important because $C$. flavescens is listed on the IUCN red list as a species of lowest risk of extinction (Lansdown 2018) and is endangered in many European countries (Hodálová et al. 1999, Korneck et al. 1996, Kaźmierczakowa et al. 2016, Grulich 2017).

The Eleocharito-Schoenoplectetum supini association with diagnostic species such as Elatine alsinastrum, Schoenoplectus supinus and Lythrum hyssopifolia has a distinct floristic and ecological layout. Our results correspond with the outcomes revealed by Šumberová \& Hrivnák 
635 (2013), which included plots with Elatine alsinastrum in the Verbenion supinae. We use the name 636 Eleocharito-Schoenoplectetum supini because of the priority of the valid name published by 637 Ubrizsy (1948). This association was found on temporary ponds in mid-field depressions that 638 occurred frequently on the uplands of Lublin region in Poland (Krawczyk et al. 2016). Formerly 639 plots with Elatine alsinastrum accompanyied with Juncus tenageia were classified to Elatino alsinastri-Juncetum tenageiae, and placed in the Eleocharition soloniensis alliance (e.g. Pietsch 1973, Täuber et al. 2007) or left rankless (Kępczyński \& Rutkowski 1991, Popiela \& Fudali 1996, Krawczyk et al. 2016). Moreover, the Elatino alsinastri-Juncetum tenageiae was considered as a synonym of Junco tenageiae-Radioletum linoidis association which was included in Radiolion alliance (Šumberová 2011b). In addition, in Pannonian Basin communities with Elatine alsinastrum were classified to Eleocharito-Schoenoplectetum supini or Elatinetum alsinastri (Nagy et al. 2009; Hrivnák \& Slezák 2017). In our data a high constancy of Alisma lanceolatum characterize the Eleocharito-Schoenoplectetum supini. This species is reported as closely related to Eleocharito palustris-Alismatetum lanceolati, which is a littoral, perenial community (Hrivnák et al. 2015). According to the formal definition of the Eleocharito-Schoenoplectetum supini, relevés with high amount of Alisma lanceolatum and without species from Isoëto-Nanojuncetea were excluded and considered as rush vegetation. In general, communities of this type are poorly understood in Europe, due the fact that they occur infrequently and often in man made habitats. Studies have shown that they can remain dormant for a very long time, even for several decades (Täuber et al. 2007, Lukács et al. 2013). During favorable conditions, their fast development is possible due to a very durable and abundant soil seed bank (Albrecht et al. 2019). The communities of this group are more associated with continental climate, for example in Hungary, where they are more common and diverse (Lukács et al. 2013). In Poland, they occur sporadically on the north-western range limit.

Among the Radiolion alliance the Centunculo-Anthoceretum punctati, the PanicoIllecebretum verticillati and the Hypericum humifusi-Spergularietum rubrae were found to be the most widespread associations. They are all distributed in the south-eastern part of Poland and develop mostly in wet furrows of arable fields. The Hyperico humifusi-Spergularietum rubrae was described by Wójcik (1968), but Popiela (1997) pointed out that this association was similar to the Panico-Illecebretum verticillati. In the Czech Republic Hyperico humifusi-Spergularietum rubrae was included in Centunculo-Anthoceretum punctati (Šumberová \& Hrivnák 2013). According to our results, both associations are clearly distinct in Poland, despite they share many diagnostics species. In Radiolion alliance, we found a new community with Montia arvensis developed on arable fields in the west part of the country. Vegetation with the dominance of Montia arvensis and Myosurus minimus has been classified so far to Centunculo-Anthoceretum punctatae, Cicendietum filiformis or Molineriello-Illecebretum verticillatae (Pietsch 1973, Brullo \& Minisalle 1998). This community seems to be well distinguished from other Radiolion linoidis communities, however, further research is required, among others a description of environmental conditions, distribution pattern and, eventually, define the association.

The first formal classification of the Isoëto-Nanojuncetea class in Poland revealed a high diversity of ephemeral vegetation found on their north-eastern distribution limits in Europe. We described two new plant communities within Eleocharition and Radiolion alliance. Although, we based on large data set, some very scarce vegetation units were recognized based on relatively small number of relevés. Hence, further research focused on rare and conservationally important ephemeral wetland vegetation is needed to present the final classification of this type of vegetation in Poland and to enable its effective conservation. Nevertheless, the results of our research show for the first 
681 time the comprehensive, reproducible in the context of analyzes, with the use of the largest

682

683

684

685

686

687

688

689

690

691

692

693

694

695

696

697

698

699

700

701

702

703

704

705

706

707

708

709

710

711

712

713

714

715

716

717

718

719

720

database, classification that is consistent with neighboring areas.

Acknowledgements

We are thankful to Mr. Marcin Dec (Florida, USA) for the linguistic revision of the manuscript. We are very grateful to Professor Ulrich Deil and to an anonymous reviewer for all comments and suggestions included in the manuscript.

\section{Literature}

Albrecht H, Pukacz A, Raabe U, Altenfelder S. 2019. Effects of habitat conditions on the diversity and species composition of plants in the soil seed bank of temporarily flooded field depressions. Phytocoenologia 49(2):149-163.

Bagi I. 1988. Ocenological relations of mud vegetation of a hypertrophic lake in the Tiszaalpár Basin. Tiscia 23:3-12

Biondi E, Blasi C, Allegrezza M, Anzellotti I, Azzella MM, Carli E, Casavecchia S, Copiz R, Del Vico E, Facioni L, Galdenzi D, Gasparri R, Lasen C, Pesaresi S, Poldini L, Sburlino G, Taffetani F, Vagge I, Zitti S, Zivkovic L. 2014. Plant communities of Italy: The Vegetation Prodrome, Plant Biosystems - An International Journal Dealing with all Aspects of Plant Biology, 148(4), 728-814, DOI: $10.1080 / 11263504.2014 .948527$

Borysiak J. 1994. Struktura aluwialnej roślinności lądowej środkowego i dolnego biegu Warty. UAM Wydawnictwo Naukowe, 254 pp.

Braun-Blanquet J. 1931. Aprecu des Groupements végétaux du Bas-Languedoc. Rapport pour l’année 1930. Comm. de la SIGMA 9, 36 pp.

Braun-Blanquet J. 1936. Un joyau floristique et phytosociologique "I'Isoëtion" méditerranéen. Comm. de la SIGMA 42:1-23.

Bruelheide H. 1997. Using formal logic to classify vegetation. Folia Geobotanica Phytotaxonomica 32:41-46.

Bruelheide H. 2000. A new measure of fidelity and its application to defining species groups. Journal of Vegetation Science 11:167-178. 
721 Bruelheide H, Chytrý M. 2000. Towards unification of national vegetation classifications: A 722 comparison of two methods for analysis of large data sets. Journal of Vegetation Science 11:295723306.

724

Bruelheide H, Dengler J, Jiménez-Alfaro B, (...). 2019. Plot-A new tool for global vegetation analyses. Journal of Vegetation Science 30:161-186. https://doi.org/10.1111/ jvs. 12710

Brullo S, Minissale P. 1998. Considerazioni syntassonomiche sulla classe Isoëto-Nanojuncetea. Itinera Geobotanica 11:263-2.

Chytrý M, Tichý L, Holt J, Botta-Dukát Z. 2002. Determination of diagnostic species with statistical fidelity measures. Journal of Vegetation Science 13:79-90.

Chytrý M, Hennekens SM, Jiménez-Alfaro B, Knollová I, Dengler J, Jansen F, Landucci F, Schaminée JHJ, Aćić S, (...) Yamalov S. 2016. European Vegetation Archive (EVA): an integrated database of European vegetation plots. Applied Vegetation Science 19:173-180.

de Foucault B. 2013. Contribution au prodrome des végétations de France : les Isoëtetea velatae de Foucault 1988 et les Juncetea bufonii de Foucault 1988 ("Isoëto - Nanojuncetea bufonii") (Partie 2). J. Bot. Soc. Bot. France, 63: 63-109.

Dajdok Z. 2009. Coleanthus subtilis (Poaceae) na terenie Stawów Milickich - nowe stanowiskow Polsce. Fragmenta Floristica Geobotanica Polonica 16(2):227-236.

Dajdok Z, Klink A, Polechońska L, Dambiec M, Pielech R. 2017. Abundance of Coleanthus subtilis in relation to nutrient concentrations in pond soils - A case study of localities in Poland. Flora - Morphology Distribution Functional Ecology of Plants 235:41-50; DOI: 10.1016/j.flora.2017.08.009

Deil U. 2005. A review on habitats, plant traits and vegetation of ephemeral wetlands - a global perspective. Phytocoenologia 35:533-705.

Deil U. 2020. Ephemeral Wetlands. In: Goldstein, MI, DellaSala, D.A. (Eds.), Encyclopedia of the World's Biomes, vol. 4. Elsevier, pp. 80-98.

De Cáceres M, Wiser SK. 2012. Towards consistency in vegetation classification. Journal of Vegetation Science 23(2):387-393. https://doi.org/10.1111/j.1654-1103.2011.01354.x 
760 Dengler J, Jansen F, Glöckler F, Pee, RK, De Cáceres M, Chytrý M, Ewald J, Oldeland J, Lopez761 Gonzalez G, (...) Spencer N. 2011. The Global Index of Vegetation-

762 Plot Databases (GIVD): a new resource for vegetation science. Journal of Vegetation Science $76322: 582-597$.

764

765

766

767

768

769

770

771

772

773

774

775

776

777

778

779

780

781

782

783

784

785

786

787

788

789

790

791

792

793

794

795

796

797

798
Dengler J, Bergmeier E, Willner W, Chytrý M. 2013. Towards a consistent classification of European grasslands. Applied Vegetation $\quad$ Science 16:518-520. https://doi.org/10.1111/avsc.12041

Douda J, Boublík K, Slezák M, Biurrun I, Nociar J, Havrdová A, Doudová J, Aćić S, Brisse H, Brunet J, Chytrý M, Claessens H, Csiky J, Didukh Y, Dimopoulos P, Dullinger S, FitzPatrick Ú, Guisan A, Horchler PJ, ... Zimmermann NE. 2016. Vegetation classification and biogeography of European floodplain forests and alder carrs. Applied Vegetation Science, 19(1):147-163. https://doi.org/10.1111/avsc.12201

Ellenberg H, Weber HE, Düll R, Wirth V, Werner W, Paulißen D. 1992. Zeigerwerte von Pflanzen in Mitteleuropa. Scripta Geobotanica 18:3-258.

Fabiszewski J, Cebrat J. 2003. Coleanthus subtilis (Tratt.) Seidel - a new species to Polish vascular flora. Acta Societatis Botanicorum Poloniae 72(2):135-138.

Grulich V. 2017. Červený seznam cévnatých rostlin ČR [The Red List of vascular plants of the Czech Republic]. - Př́roda 35: 75-132.

Hrivnák R, Slezák M. 2017. Two interesting wetland plant communities from the Ipel' River inundation area, including the first record of Elatinetum alsinastrum in Slovakia. Thaiszia - Journal of Botany 27(2):73-82.

Hrivnák R, Slezák M, Šumberová K, Hroudová Z. 2015. A new marsh plant community of Eleocharito palustris-Alismatetum lanceolati (Eleocharito palustris-Sagittarion sagittifoliae alliance) in Slovakia. Acta Soc. Bot. Pol. 84(3):311-319. DOI: 10.5586/asbp.2015.026.

Horvatić S. 1931. Die verbreitesten Pflanzengesellschaften der Wasser- und Ufervegetation in Kroatien und Slavonien. Acta Bot. Inst. Univ. Zagreb. 6:91-108.

Hodálová I, Feráková V, Procházka F. 1999. Pycreus flavescens (L.) Reichenb. In: Čeřovský J, Feráková V, Holub J, Maglocký Š, Procházka F, Elias sen P, editors. Červená kniha ohrozených a vzácnych druhov rastlín a živočíchov SR a ČR 5. Vyššie rastliny. Bratislava; Priroda: 1999. 
799 Janišová M, Dúbravková D. 2010. Formalized classification of rocky Pannonian grasslands and 800 dealpine Sesleria-dominated grasslands in Slovakia using a hierarchical expert system. 801 Phytocoenologia 40:267-291.

802

803

804

805

806

807

808

809

810

811

812

813

814

815

816

817

818

819

820

821

822

823

824

825

826

827

828

829

830

831

832

833

834

835

836

837

838
Kaźmierczakowa R, Bloch-Orłowska J, Celka Z, Cwener A, Dajdok Z, Michalska-Hejduk D, Pawlikowski P, Szczęśniak E, Ziarnek K. 2016. Polska czerwona lista paprotników i roślin kwiatowych. Polish red list of pteridophytes and flowering plants. $44 \mathrm{pp}$. Instytut Ochrony Przyrody Polskiej Akademii Nauk, Kraków.

Kącki Z, Śliwiński M. 2012. The Polish Vegetation Database: structure, resources and development. Acta Societatis Botanicorum Poloniae 81:75-79.

Kącki Z, Czarniecka M, Swacha G. 2013. Statistical determination of diagnostic, constant and dominant species of the higher vegetation units of Poland. Monographiae Botanicae 103:1-267.

Kącki Z, Swacha G, Lengyel A, Korzeniak J. 2020. Formalised hierarchically nested expert system for classification of mesic and wet grasslands in Poland. Acta Societatis Botanicorum Poloniae 89(4), doi.org/10.5586/asbp.8941

Kępczyński K, Rutkowski L. 1991. Występowanie Alisma lanceolatum With. w różnych zbiorowiskach roślinnych na terenie otaczającym dolną i środkową Wisłę. Acta Universitatis Nicolai Copernici, Biologia 38:93- 103.

Koch W. 1926. Die Vegetationseinheiten der Linthebene unter Berück sichtigung der Verhältnisse in der Nordostschweitz. Jb. St. Gall. Naturw. Ges. 61,2:1-146.

Kornaś J. 1960. Centunculo-Anthoceretum w dolinie górnej Wisły. Fragmenta Floristica Geobotanica 6, 4:517-521.

Korneck D. 1960. Beobachtungen an Zwergbinsengesellschaften im Jahre 1959. Beitr. Naturk. Forsch. SW-Dtschl. 19: 101-110.

Korneck, D, Schnittler, M. \& Vollmer, I. 1996. Rote Liste der Farn- und Blütenpflanzen (Pteridophyta et Spermatophyta) Deutschlands. - Schriftenreihe für Vegetationskunde 28: 21-187

Krawczyk R, Cwener A, Michalczuk W, Zubel Z. 2016. Ephemeral wetland communities of Isoëto-Nano-Juncetea class - new data from south-eastern Poland. Biodiversity. Research and Conservation 42:41-54. 
839 Lampe M, von (1996): Wuchsform, Wuchsrhythmus und Verbreitung der Arten der

840

841

842

843

844

845

846

847

848

849

850

851

852

853

854

855

856

857

858

859

860

861

862

863

864

865

866

867

868

869

870

871

872

873

874

875

876

877

878

Zwergbinsengesellschaften. Dissertatione Botanicae 266:1-353

Landucci F, Tichý L, Šumberová K, Chytrý M. 2015. Formalized classification of species-poor vegetation: a proposal of a consistent protocol for aquatic vegetation. Journal of Vegetation Science 26(4):791-803. https://doi.org/10.1111/jvs.12277

Landucci F, Šumberová K, Tichý L, Hennekens S, Aunina L, Biţă-Nicolae C, Borsukevych L, Bobrov A, Čarni A, Bie E, Golub V, Hrivnák R, Iemelianova S, Jandt U, Jansen F, Kącki Z, Lájer K, Papastergiadou E, Šilc U, (...) Chytrý M. 2020. Classification of the European marsh vegetation (Phragmito-Magnocaricetea ) to the association level. Applied Vegetation Science 23(2):297-316. https://doi.org/10.1111/avsc.12484

Libbert W. 1932. Die Vegetationseinheiten der neumärkischen Staubeckenlandschaft unter besonderer Berücksichtigung der angrenzenden Landschaften. I. Verh. Bot. Ver. Branden. 74:1093.

Lansdown, R.V. 2018. Cyperus flavescens. The IUCN Red List of Threatened Species 2018: e.T157979A120157948.https://dx.doi.org/10.2305/IUCN.UK.2018-

2.RLTS.T157979A120157948.en. Downloaded on 30 March 2021.

Lukács BA, Sramkó G, Molnár A. 2013. Plant diversity and conservation value of continental temporary pools. Biological Conservation 158:393-400.

Marciniuk P, Marciniuk J, Łysko A, Krajewski Ł, Chudecka J, Skrzyczyńska J, Popiela A. 2020. Rediscovery of Cyperus flavescens (Cyperaceae) on the northeast periphery of its range in Europe. PeerJ 8:e9837 https://doi.org/10.7717/peerj.9837

Matuszkiewicz W. 2007. Przewodnik do oznaczania zbiorowisk roślinnych Polski. Ed. 3. Wydawnictwo Naukowe PWN, Warszawa. 537 pp

Moor M. 1936. Zur Soziologie der Isoëtalia. Beitr. Geobot. Landesaufn. Schweiz 20:1-148

Moor M. 1937. Ordnung der Isoëtalia (Zwergbinsengesellschaften). Prodomus der Pflanzengesellschaften 4:1-24.

Mucina L, Bültmann H, Dierssen K, Theurillat J-P, Raus T, Čarni A, Šumberová K, Willner W, Dengler J. (...) Tichý L. 2016. Vegetation of Europe: hierarchical floristic classification system of vascular plant, bryophyte, lichen, and algal communities. Applied Vegetation Science 19(Suppl. 1): 3-264.

Peer) reviewing PDF | (2020:11:55719:2:1:NEW 23 May 2021) 
879

880

881

882

883

884

885

886

887

888

889

890

891

892

893

894

895

896

897

898

899

900

901

902

903

904

905

906

907

908

909

910

911

912

913

914

915

916

917

918

Müller-Stoll WR, Pietsch W. 1985. Ökologische Untersuchungen über die Gesellschaft des Eleocharito-Caricetum bohemicae auf wasserfrei gewordenen Teichböden in Zentraleuropa. Verh. Zool.-Bot. Ges. Österreich 123: 51-70.

Nagy J, Gal B, Cserhalmi D, Fogarasi G, Rabnecz G. 2009. Flood as stress which increases the natural value of the depressions of arables on the Hungarian Bodrogkoz. Cereal Research Communication 37:497-500

Nikolić T, Topić J. 2005. Red book of vascular flora of Croatia. Zagreb: Ministry of Culture, State Institute for Nature Protection, Republic of Croatia

Nowak A, Nobis M, Nowak S, Nobis A, Swacha G, Kacki Z. 2017. Vegetation of middle Asia The project state of art after ten years of survey and future perspectives. Phytocoenologia 47(4): $395-400$

Oberdorfer E. 1957. Süddeutsche Pflanzengesellschaften. - Pflanzensoziologie 10: 1-564.

Oberdorfer E. 1977. Süddeutsche Pflanzengesellschaften. Teil I. Stuttgart. 311 pp

Oksanen J, Blanchet FG, Friendly M, Kindt R, Legendre P, Mcglinn D, Minchin P.R, O'hara R.B, Simpson G.L, Solymos P, Stevens MHH, Szoecs E. \& Wagner H. 2011.

Vegan: Community Ecology Package.

Poschlod P, Abedi M, Bartelheimer M, Drobnik J, Rosbakh S, Saatkamp A. 2013. Seed ecology and assembly rules in plant communities. In: van der Maarel E, Franklin, J.(eds).Vegetation ecology, 2nd edn, pp. 164-202, Wiley-Black-well, Chichester, UK.

Pietsch W. 1965. Beiträge zur Gliederung der europäischen Zwergbinsengesellschaften. Vegetatio $13: 1-37$.

Pietsch W. 1969. Die Teiche bei Peitz und ihre sekundäre Teichbodenvegetation. Niederlau. Flor. Mitt. 5:2-11.

Pietsch W. 1973. Beitrag zur Gliederung der europäischen Zwergbinsengesellschaften (IsoëtoNanojuncetea Br.-Bl. et Tx. 1943). Vegetatio 28 (5-6):401-438.

Pietsch W, Müller-Stoll WR. 1968. Die Zwergbinsen-Gesellschaft der nackten Teichböden im Östlichen Mitteleuropa, Eleocharito-Caricetum bohemicae. Mitteilungen FloristischSoziologischen Arbeitsgemeinschaft N. F. 13:14-47 
919

920

921

922

923

924

925

926

927

928

929

930

931

932

933

934

935

936

937

938

939

940

941

942

943

944

945

946

947

948

949

950

951

952

953

954

955

956

957

958

Pietsch W, Müller-Stoll WR. 1974. Übersicht über die im brandenburgischen Gebiet vorkommenden Zwergbinsen-Gesellschaften (Isoëto-Nanojuncetea). Verh. Bot. Ver. Branden. 109:56-95.

Popiela A. 1997. Occurrence of the Isoëto-Nanojuncetea class communities in Poland. Monographie Botanicae 80:1-59.

Popiela A. 2005. Isoëto-Nanojuncetea species and plant communities in their eastern distribution range (Poland). Phytocoenologia 35(2-3):283-303.

Popiela A, Fudali E. 1996. The community with Elatine alsinastrum (The Isoëto-Nanojunceteaclass) in the town Chojna environs in the western Pomerania (NW Poland). Fragmenta Floristica Geobotanica 38(2):771-774.

Rašomavičius V, Biveinis A. 1996. The communi-ties of Isoeto-Nanojuncetea bufonii Br.-Bl. et R. Tx. 1943 class in Lithuania. Botanica Lithuanica 2(1): 3-27.

Rivas Goday S. 1970. Revisión de las comunidades hispanas de la clase Isoëto-Nanojuncetea Br.B1. \& Tüxen 1943. Anales Inst. Bot. Cavanilles 27:225-276.

Sokal RR, Rohlf FJ. 1995. Biometry: The Principles and Practice of Statistics in Biological Research. 3rd ed. W.H. Freeman, New York: 880 pp.

Richert E, Achtziger R, Dajdok Z, Günther A, Heilmeier H, Hübner A, John H, Šumberová K. 2016. Rare wetland grass Coleanthus subtilis in Central and Western Europe - current distribution, habitat types, and threats. Acta Societatis Botanicorum Poloniae 83(3):1-16.

DOI: $10.5586 /$ asbp.3511

Šilc U, Čarni A. 2007. Formalized classification of the weed vegetation of arable land in Slovenia. Preslia 79: 283-302.

Sikora J. 2012. Wielofunkcyjność obszarów wiejskich w Polsce. Journal of Agribusiness and Rural Development 2(24): 215-226

Spałek K, Nowak A. 2006. Zbiorowiska namułkowe z klasy Isoëto-Nanojuncetea w zbiornikach zaporowych na Śląsku Opolskim. Fragmenta Floristica Geobotanica Polonica 13(2):361-368.

Strech A. 1941. Lindernia pyxidaria in der Mark Brandenburg. Verh. Bot. Ver. Branden. 81: 165167. 
959

960

961

962

963

964

965

966

967

968

969

970

971

972

973

974

975

976

977

978

979

980

981

982

983

984

985

986

987

988

989

990

991

992

993

994

995

996

997
Swacha G, Kącki Z, Załuski T. 2016. Classification of Molinia meadows in Poland using a hierarchical expert system. Phytocoenologia 46(1):33-47. https://doi.org/10.1127/phyto/2016/0094

Šumberová K. 2011a. Cyperetum micheliani Horvatić 1931. - In: Chytrý M. (ed.), Vegetace České republiky. 3. Vodní a mokřadní vegetace [Vegetation of the Czech Republic 3. Aquatic and wetland vegetation], p. 319-324, Academia, Praha.

Šumberová K. 2011b. Junco tenageiae-Radioletum linoidis Pietsch 1963. - In: Chytrý M. (ed.), Vegetace České republiky. 3. Vodní a mokřadní vegetace [Vegetation of the Czech Republic 3. Aquatic and wetland vegetation], p. 333-336, Academia, Praha.

Šumberová K, Hrivnák R. 2013. Formalised classification of the annual herb vegetation of wetlands (Isoëto-Nano-Juncetea class) in the Czech Republic and Slovakia (Central Europe). Phytocoenologia 43(1,2):13-40 DOI 10.1127/0340-269X/2013/0043-0529.

Taran G. 2019. Ephemeral Wetland Vegetation of the Ob River in the Forest-Steppe Zone of Western Siberia. Journal of Siberian Federal University - Biology 12(1): 15-31

Täuber T. 2000. Zwergbinsen-Gesellschaften (Isoëto-Nanojuncetea) in Niedersachsen. Verbreitung, Gliederung, Dynamik, Keimungsbedingungen der Arten und Schutzkonzepte. Cuvillier Verlag, Göttingen. 238 pp.

Täuber T, Petersen J. 2000. Isoëto-Nanojuncetea, Zwergbinsen-Gesellschaften. - In: H. Dierschke H. (ed.): Formalised classifi cation of the annual herb vegetation of wetlands 39

Synopsis der Pfl anzengesellschaften Deutschlands, Vol. 7, pp. 1-87. - Floristisch-soziol. Arbeitsgemein. Göttingen.

Täuber T, Bruns E, Steinhoff KJ. 2007. Wiederfund des Elatino alsinastri-Juncetum tenageiae Libb. 1932 in Niedersachsen - Lebensbedingungen, Syndynamik und Schutzbemühungen. Hercynia N.F. 40:269-278.

Tichý L. 2002. JUICE, software for vegetation classification. Journal of Vegetation Science, 13:451-453.

Tüxen R. 1973. Bibliographia Phytosociologica Syntaxonomica. Lieferung 19: IsoëtoNanojuncetea. J. Cramer Verlag, Lehre, 90 pp.

Peer) reviewing PDF | (2020:11:55719:2:1:NEW 23 May 2021) 
998 Ubrizsy G. 1948. A rizs hazai gyomnövényzete. (La végétation des mauvaises herbes dans les 999 cultures de riz en Hongrie). Acta Agrobotanica Hungarica 1(4):1-43.

1000

1001 Willner W, Rolecek J, Korolyuk A, Dengler J, Chytrý M, Janišová M, Lengyel A, Acic S, Becker 1002 T, Cuk M, (...) 2019. Formalized classification of semi-dry grasslands in central and eastern 1003 Europe. Preslia 91(1): 25-49

1004

1005

1006

1007

1008

Wójcik Z. 1968. Les associations des champs cultivés en Masovie. II. Les associations de chaumes de l'alliance Nanocyperion flavescentis. Ekologia Polska Ser. A 16(3): 101-120.

Zając M, Zając A. 1988. Zbiorowiska z klasy Isoëto-Nanojuncetea na dnach wysychających stawów w południowej części Kotliny Oświęcimskiej. Zeszyty Naukowe Uniwersytetu Jagiellońskiego, Prace Bot. 17:155-160. 


\section{Table $\mathbf{1}$ (on next page)}

List of sociological species groups used for formal definitions of syntaxa 


\begin{tabular}{|c|c|}
\hline Species group & Species \\
\hline \# TC Isoëto-Nanojuncetea class & $\begin{array}{l}\text { Anagallis minima, Anthoceros punctatus s. l., Cardamine parviflora, Carex bohemica, } \\
\text { Centaurium pulchellum, Cerastium dubium, Coleanthus subtilis, Crassula aquatica, Cyperus } \\
\text { fuscus, Cyperus michelianus, Cyperus esculentus, Elatine alsinastrum, Elatine hexandra, } \\
\text { Elatine hydropiper, Elatine triandra,Eleocharis acicularis, Eleocharis ovata, Fossombronia } \\
\text { wondraczekii, Gnaphalium uliginosum, Gratiola neglecta, Gypsophila muralis, Hypericum } \\
\text { humifusum, Illecebrum verticillatum, Isolepis setacea, Juncus bufonius, Juncus capitatus, } \\
\text { Juncus ranarius, Juncus tenageia, Laphangium luteoalbum, Limosella aquatica, Lindernia } \\
\text { dubia, Lindernia procumbens, Lythrum hyssopifolia, Lythrum portula, Mentha pulegium, } \\
\text { Montia arvensis, Myosurus minimus, Phaeoceros laevis, Plantago major subsp. intermedia, } \\
\text { Potentilla supina, Pulicaria vulgaris, CyperusCyperus flavescens, Radiola linoides, } \\
\text { Ranunculus sardous, Riccia beyrichiana, Riccia bifurca, Riccia canaliculata, Riccia } \\
\text { cavernosa, Riccia ciliifera, Riccia crystallina, Riccia duplex, Riccia huebeneriana, Riccia } \\
\text { warnstorfii, Riccia glauca, Riccia sorocarpa, Sagina apetala, Sagina nodosa, Schoenoplectus } \\
\text { supinus, Spergularia echinosperma, Spergularia rubra, Veronica anagalloides, Veronica } \\
\text { catenata, Veronica peregrina }\end{array}$ \\
\hline \#TC Eleocharition soloniensis & $\begin{array}{l}\text { Carex bohemica, Coleanthus subtilis, Crassula aquatica, Cyperus fuscus, Cyperus } \\
\text { michelianus, Elatine hexandra, E. hydropiper, E. triandra, Eleocharis ovata, Limosella } \\
\text { aquatica, Lindernia dubia, L. procumbensPotentilla supina, Riccia canaliculata, Riccia } \\
\text { cavernosa }\end{array}$ \\
\hline \#TC Radiolion & $\begin{array}{l}\text { Anagallis minima, Anthoceros punctatus s.l., Fossombronia wondraczekii, Gypsophila } \\
\text { muralis, Hypericum humifusum, Illecebrum verticillatum, Isolepis setacea, Juncus capitatus, } \\
\text { Montia arvensis, Phaeoceros laevis, Radiola linoides, Ranunculus sardous, Spergularia } \\
\text { rubra }\end{array}$ \\
\hline \#TC Verbenion & $\begin{array}{l}\text { Elatine alsinastrum, Juncus ranarius, Lythrum hyssopifolia, Mentha pulegium, Pulicaria } \\
\text { vulgaris, Cyperus flavescens, Schoenoplectus supinus }\end{array}$ \\
\hline \#\#\# Cyperus fuscus & Cyperus fuscus, Potentilla supina, Limosella aquatica \\
\hline \#\#\# Elatine alsinastrum & Alisma lanceolatum, Elatine alsinastrum, Schoenoplectus supinus \\
\hline \#\#\# Elatine hexandra & Elatine hexandra, Elatine triandra, Elatine hydropiper \\
\hline \#\#\# Eleocharis ovata & Carex bohemica, Eleocharis ovata, Lindernia procumbens \\
\hline \#\#\# Myosurus minimus & Bryum ruderale, Myosurus minimus, Ranunculus sardous \\
\hline \#\#\# Centunculus minimus & Anthoceros punctatus s. l., Anagallis minima, Juncus capitatus, Radiola linoides \\
\hline \#\#\# Gypsophila muralis & Gypsophila muralis, Laphangium luteoalbum, Spergularia rubra \\
\hline \#\#\# Isolepis setacea & Isolepis setacea, Juncus tenageia, Stellaria alsine \\
\hline
\end{tabular}




\section{Table 2 (on next page)}

Number of relevés of identified plant communities of the Isoëto-Nanojuncetea class in Poland 


\begin{tabular}{|l|l|l|}
\hline Cluster & Syntaxon & $\begin{array}{l}\text { No. of } \\
\text { relevés }\end{array}$ \\
\hline A & Eleocharition soloniensis Philippi 1968 & 272 \\
\hline 1 & Polygono-Eleocharitetum ovatae Eggler 1933 & 129 \\
\hline 2 & Cypero fusci-Limoselletum aquaticae Oberd. ex Korneck 1960 & 127 \\
\hline 3 & Cyperetum micheliani Horvatić 1931 & 4 \\
\hline 4 & Community with Coleanthus subtilis & 12 \\
\hline B & Verbenion supinae Slavnić 1951 ex & 46 \\
\hline 5 & $\begin{array}{l}\text { Veronico anagalloidis-Lythretum hyssopifoliae Wagner ex } \\
\text { Holzner 1973 }\end{array}$ & 3 \\
\hline 6 & Cyperetum flavescentis Koch 1926 & 8 \\
\hline 7 & Pulicario vulgaris-Menthetum pulegii Slavnić 1951 & 19 \\
\hline 8 & $\begin{array}{l}\text { Eleocharito-Schoenoplectetum supini Soo \& Ubrizsy 1948 nomina } \\
\text { inversa prop. }\end{array}$ & 16 \\
\hline C & Radiolion linoidis Pietsch 1973 & 223 \\
\hline 9 & Stellario uliginosae-Isolepidetum setaceae Libbert 1932 & 20 \\
\hline 10 & Centunculo minimi-Anthoceretum punctati Koch ex Libbert 1932 & 90 \\
\hline 11 & Hyperico humifusi-Spergularietum rubrae Wójcik 1968 & 42 \\
\hline 12 & Panico-Illecebretum verticillati Diemont \& al. 1940. & 47 \\
\hline 13 & Cerastio-Ranunculetum sardoi Oberdorfer ex Vicherek 1968 & 9 \\
\hline 14 & Community with Montia arvensis & 15 \\
\hline
\end{tabular}

1 


\section{Figure 1}

DCA ordination diagram of samples of Isoëto-Nanojuncetea communities

The first two ordination axes explain $34.8 \%$ and $36.6 \%$ total species-environment relations variability, and explain $3.0 \%$ and $5.2 \%$ of the entire species variability $(n=541)$. The center of centroids marked by colored number. (A) Eleocharition ovatae. (B) Verbenion supinae. (C) Radiolion linoidis. The Ellenberg indicators - LIGHT - Light; TEMP - Temperature; CONT Continentality; MOIST - Moisture; REACT - Soil Reaction; NUTR - Nutrient - were plotted as supplementary variables. 


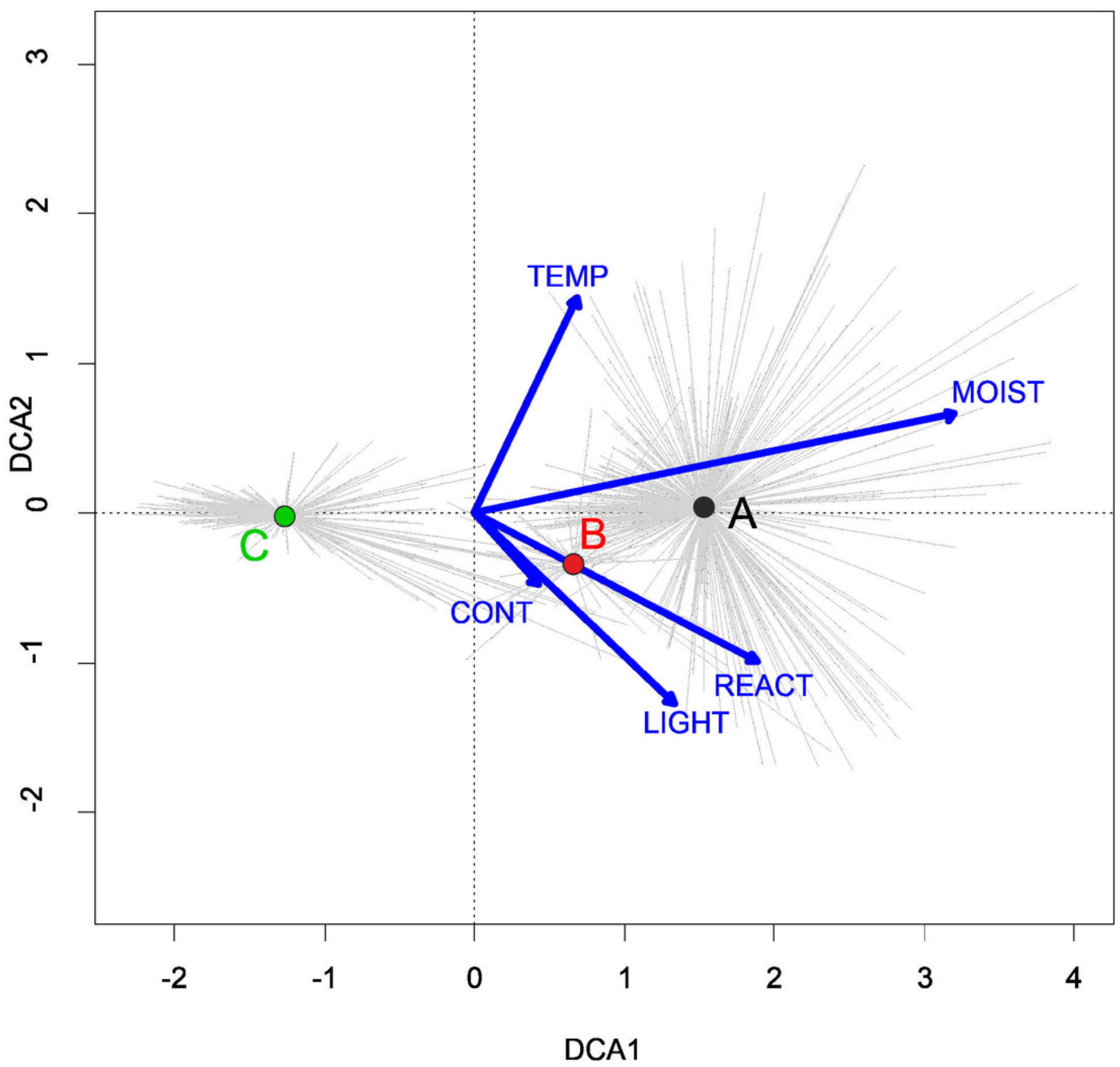


Figure 2

Distribution of plant communities of the Isoëto-Nanojuncetea class in Poland

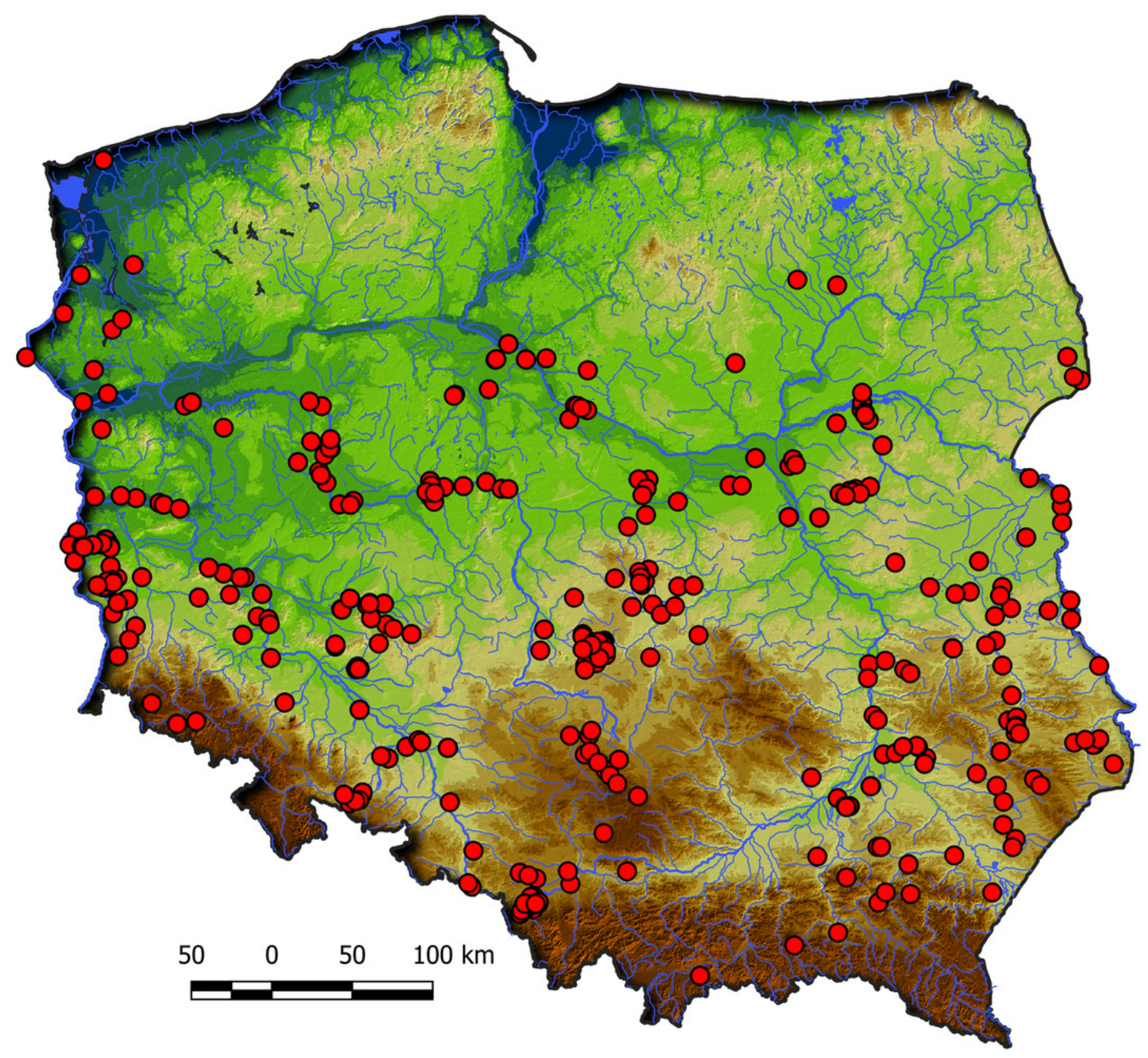




\section{Figure 3}

The ranges of alliances of Isoëto-Nanojuncetea class in Poland
(A) Eleocharition soloniensis. (B) Verbenion supinae. (C) Radiolion linoidis.
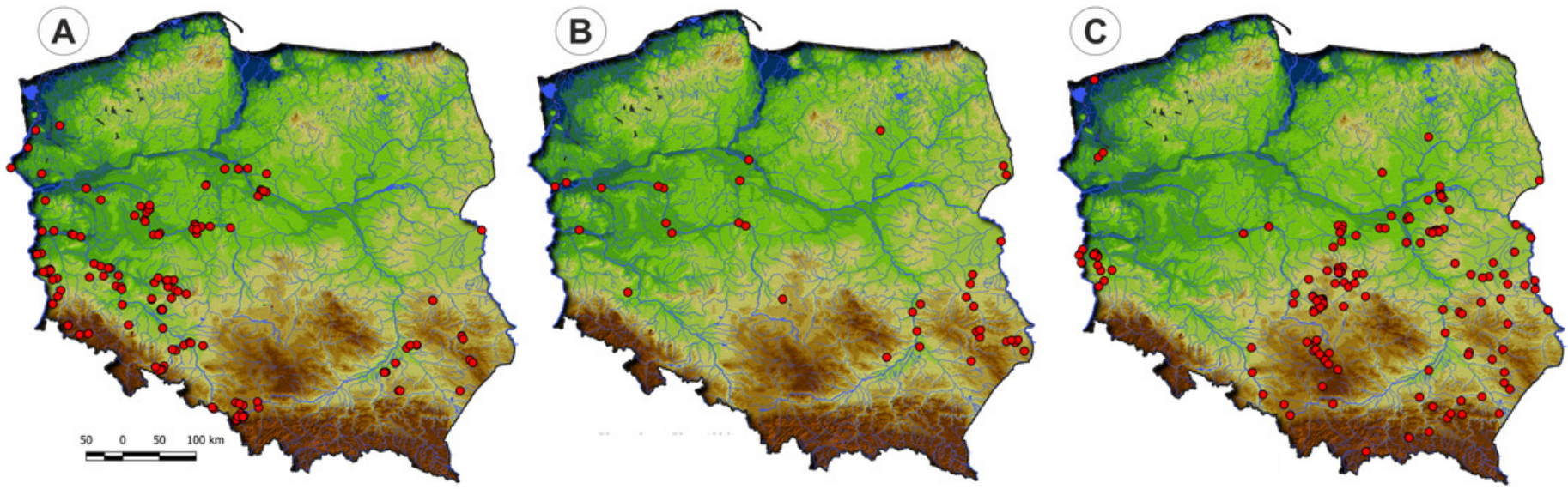
Figure 4

Distribution of plant communities of the Eleocharition soloniensis alliance in Poland (A) Polygono-Eleocharitetum ovatae. (B) Cypero-Limoselletum aquaticae. (C) Cyperetum micheliani. (D) community with Coleanthus subtilis.
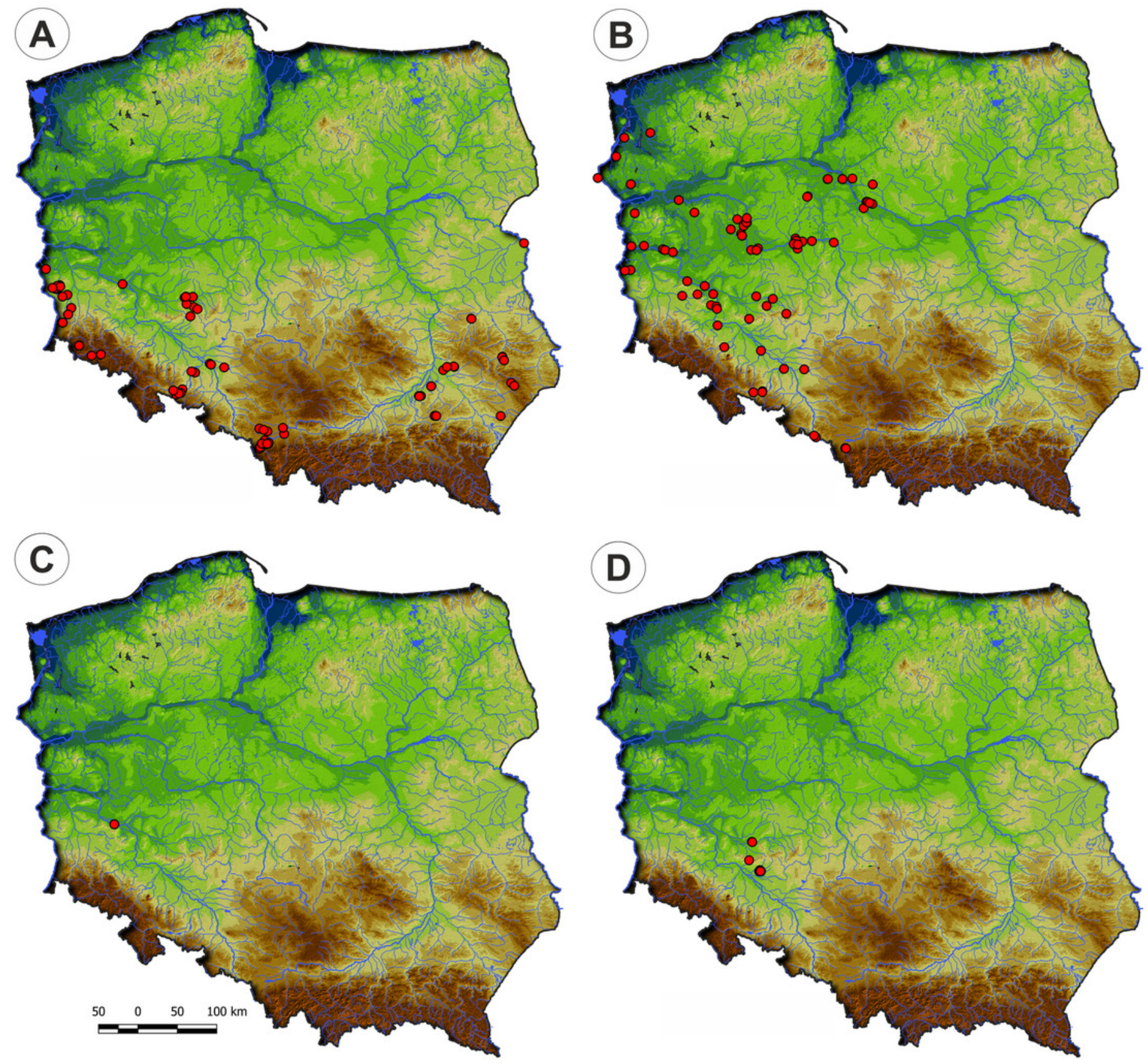


\section{Figure 5}

Vegetation of the Eleocharition soloniensis alliance

(A, B, C, D) phytocoenoses of the Polygono-Eleocharetum ovatae in different stages of development (Photos by R. Krawczyk, S. Rosadziński, A. Popiela). (E, F) phytocoenoses of Cypero-Limoselletum (Photos by S. Rosadziński). (G, H) phytocoenoses of the Cyperetum micheliani (Photos by Z. Kącki). (I, J) community with Coleanthus subtilis (Photo by Z. Dajdok). 


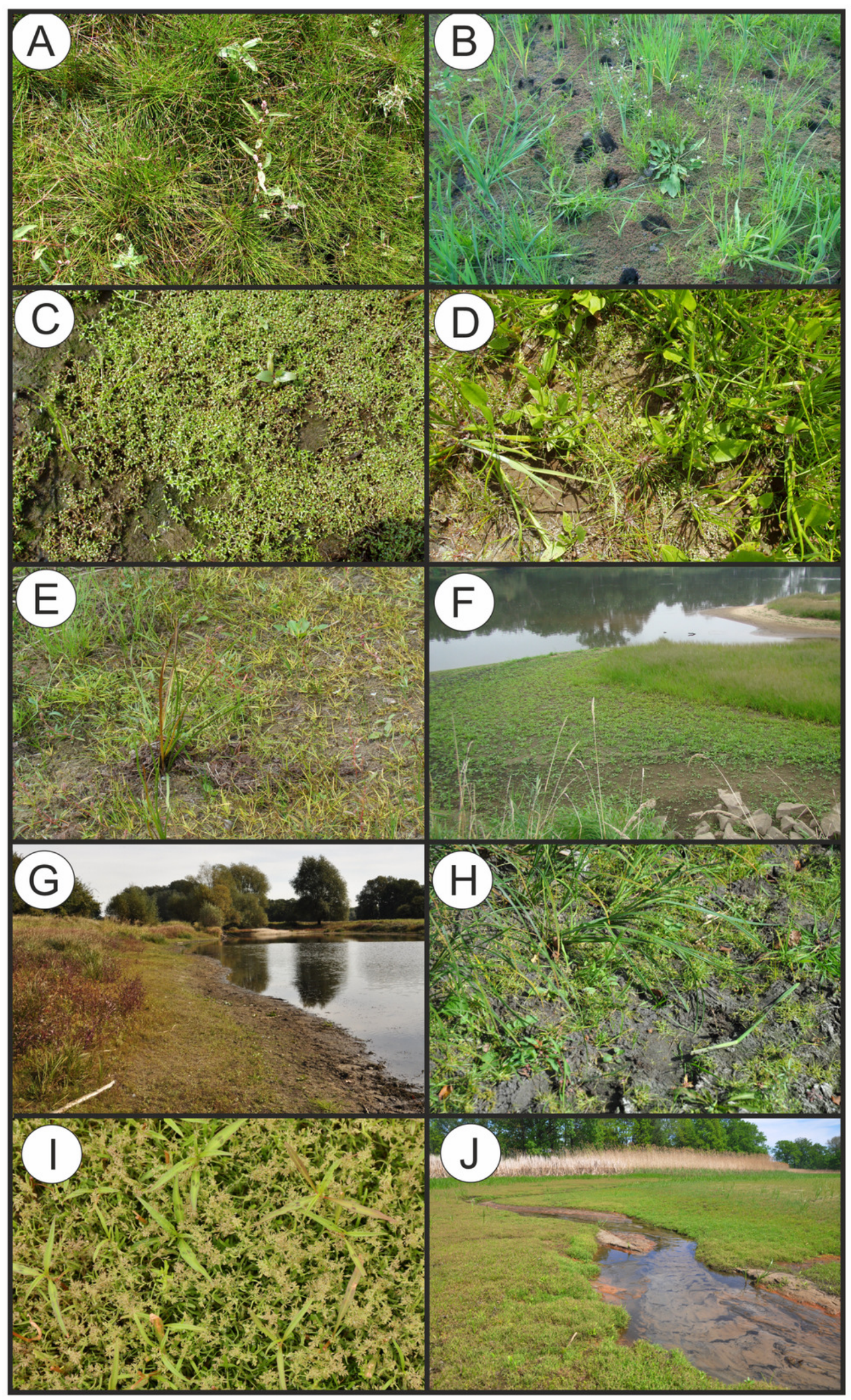




\section{Figure 6}

DCA ordination diagram of samples of Eleocharition soloniensis vegetation

. The first two ordination axes explain $23.9 \%$ and $27.8 \%$ of the total species-environment relations variability, and additional explain $3.8 \%$ and $6.7 \%$ of the total species variability $(n=272)$. Colored dots mark the center of centroids. (A) Polygono-Eleocharitetum ovatae. (B) Cypero-Limoselletum aquaticae. (C) Cyperetum micheliani. (D) community with Coleanthus subtilis. The Ellenberg indicators: LIGHT - Light; TEMP - Temperature; CONT - Continentality; MOIST - Moisture; REACT - Soil Reaction; NUTR - Nutrient were plotted as a supplementary variables. 


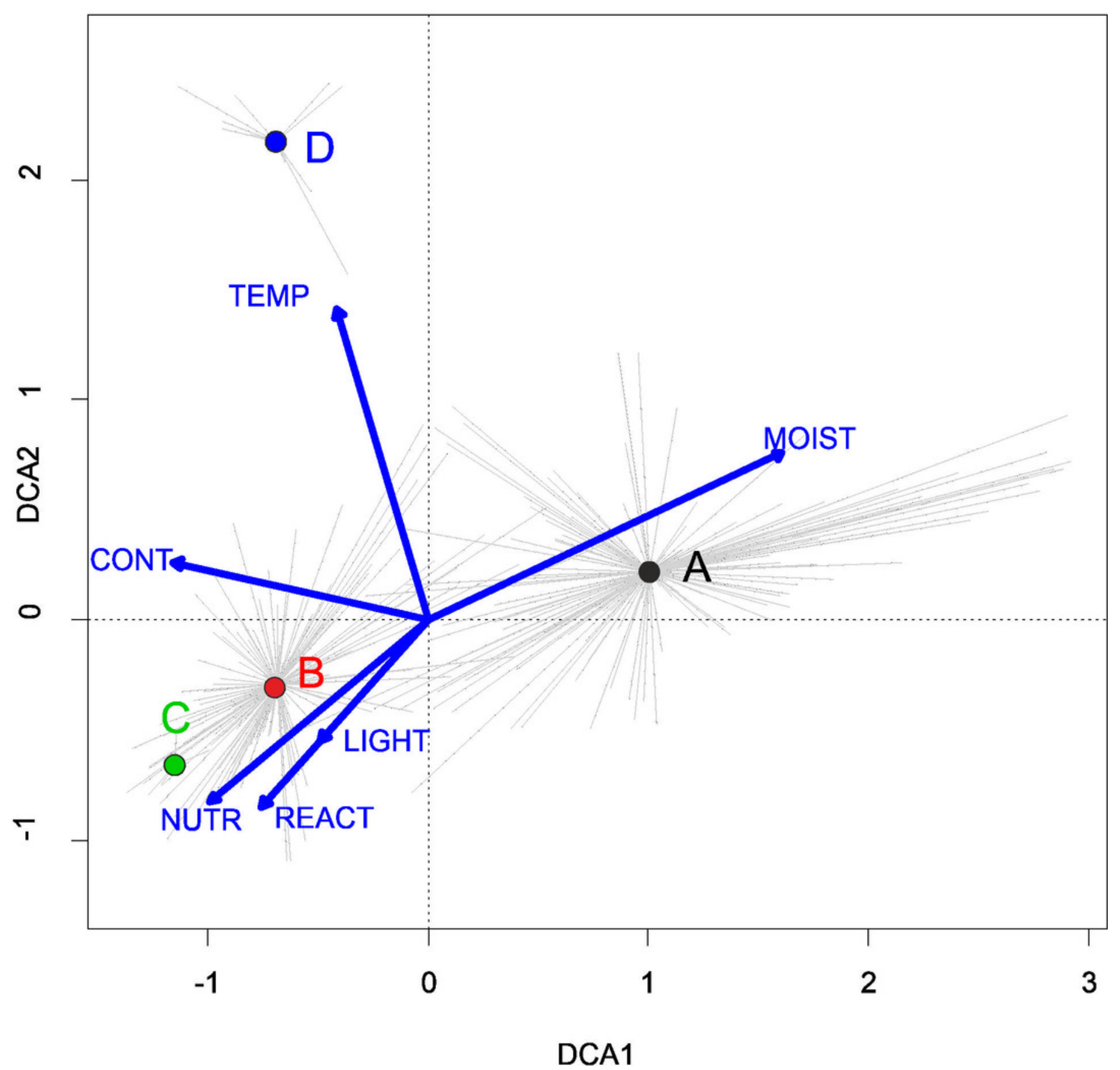




\section{Figure 7}

DCA ordination diagram of samples of Verbenion supinae plant communities

The first two ordination axes explain $21.2 \%$ and $32.7 \%$ of the total species-environment relations variability, and explain $8.0 \%$ and $14.4 \%$ of the total species variability $(n=46)$. (A) Veronico anagalloidis-Lythretum hyssopifoliae. (B) Cyperetum flavescentis. (C) Pulicario vulgaris-Menthetum pulegii. (D) Eleocharito-Schoenoplectetum supini. The Ellenberg indicators:- LIGHT - Light; TEMP - Temperature; CONT - Continentality; MOIST - Moisture; REACT - Soil Reaction; NUTR - Nutrient - were plotted as a supplementary variables. 


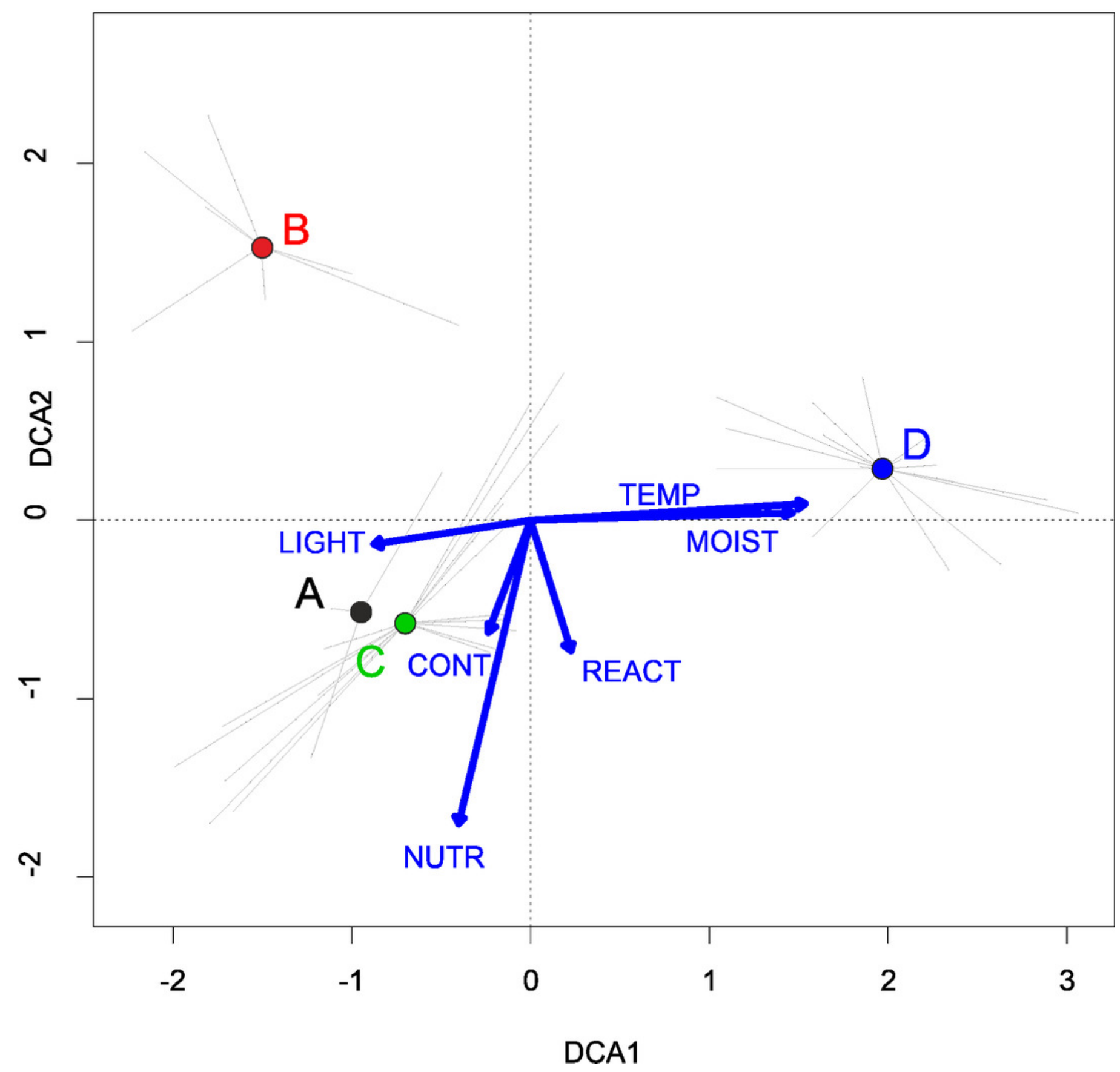


Figure 8

Distribution of plant communities of the Verbenion supinae alliance in Poland

(A) Veronico anagalloidis-Lythretum hyssopifoliae. (B) Cyperetum flavescentis. (C) Pulicario vulgaris-Menthetum pulegii. (D) Eleocharito-Schoenoplectetum supini .
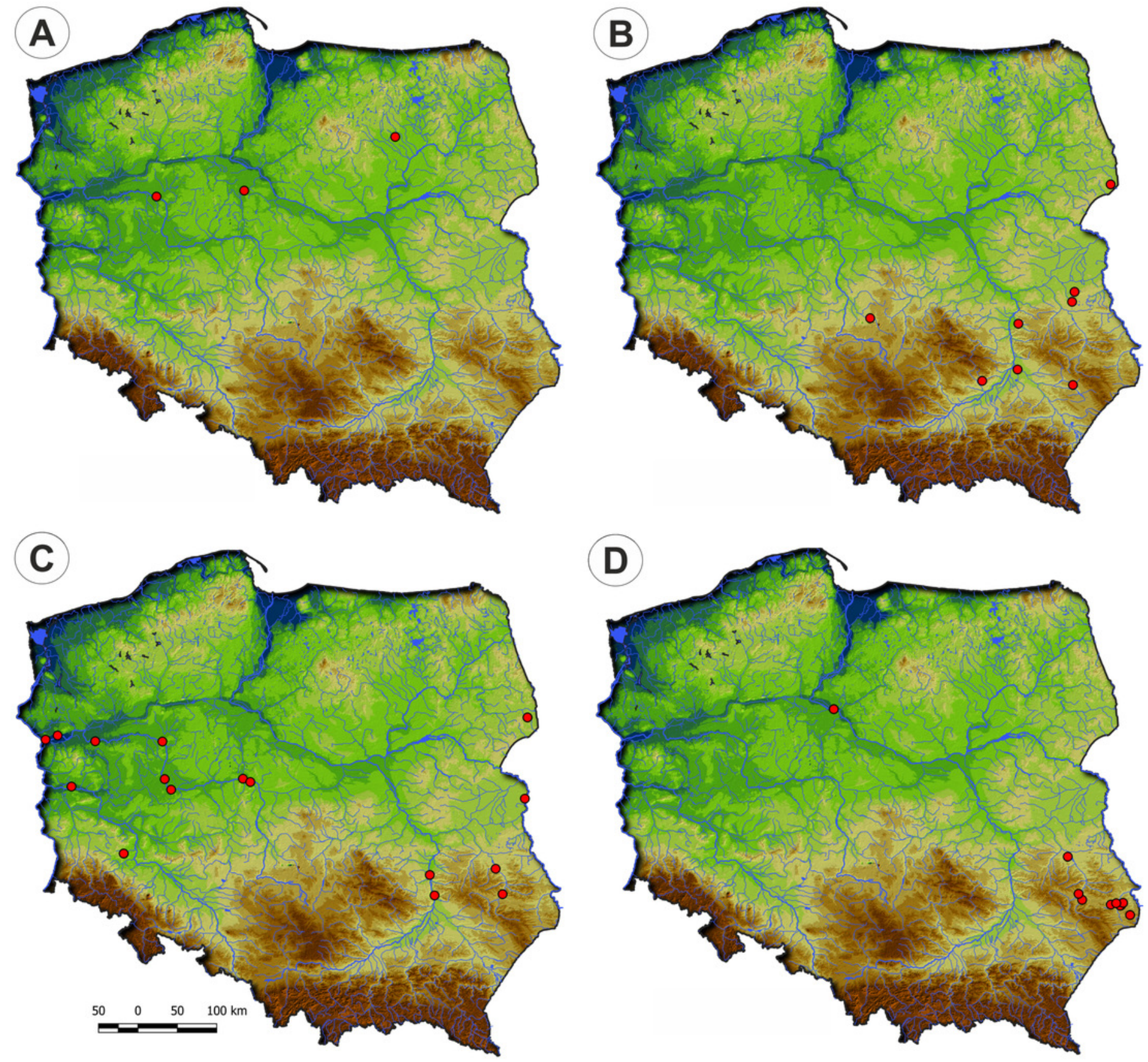
Figure 9

Vegetation of the Verbenion supinae alliance

(A) phytocoenose of the Cyperetum flavescentis association. (B) a temporary pool in arable field depressions with patches of the Eleocharito-Schoenoplectetum supini (brown belt). (C, D) phytocoenoses of the Eleocharito-Schoenoplectetum supini in different stages of development (Photo by R. Krawczyk).

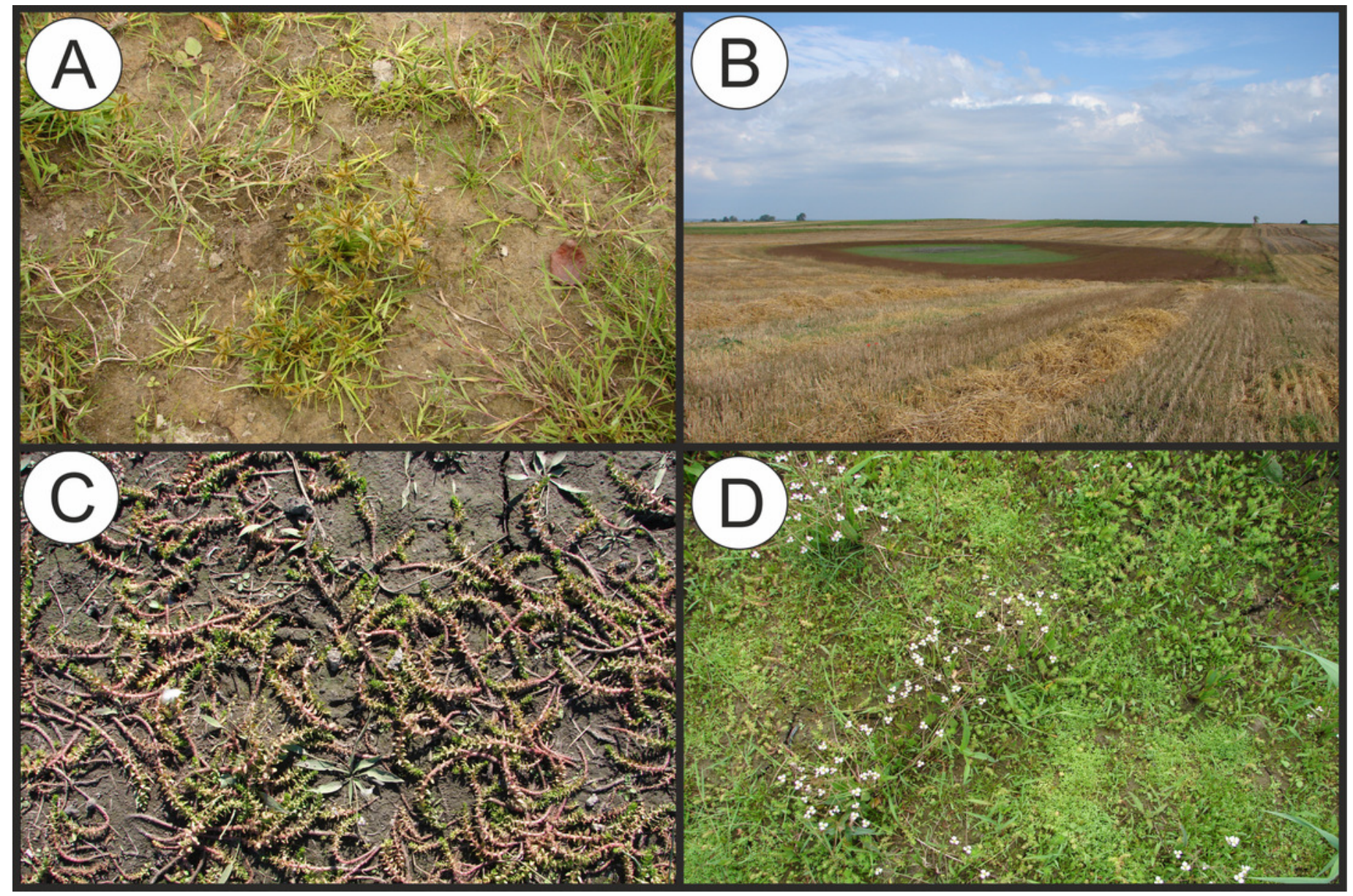




\section{Figure 10}

Distribution of the plant communities of the Radiolion linoidis alliance in Poland

(A) Stellario uliginosae-Isolepidetum setaceae. (B) Centunculo minimi-Anthoceretum punctati.

(C) Hyperico humifusi-Spergularietum rubrae. (D) Panico-Illecebretum verticillati. (E) Cerastio dubii-Ranunculetum sardoi. (F) Community with Montia arvensis. 

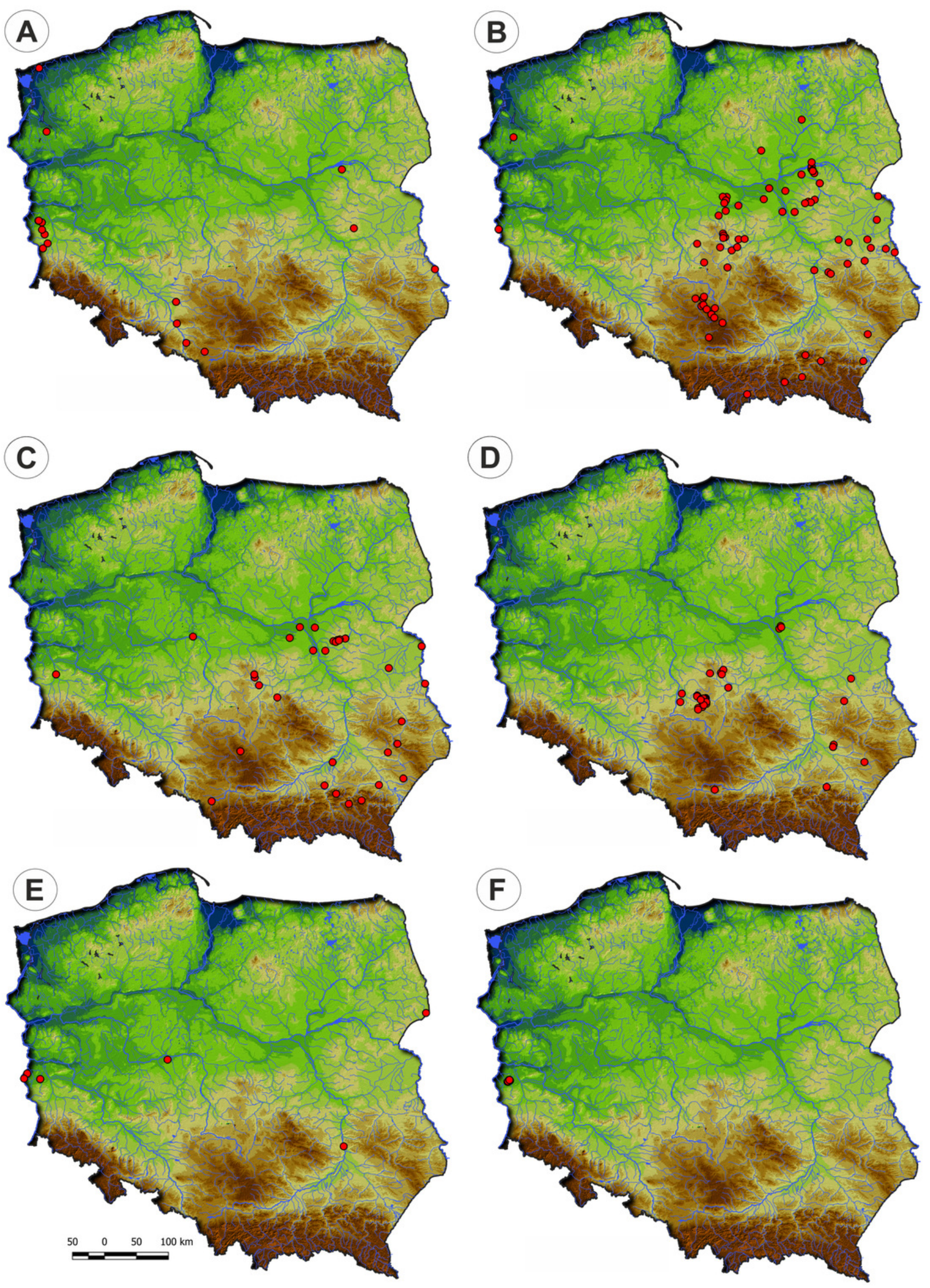

Peer) reviewing PDF | (2020:11:55719:2:1:NEW 23 May 2021) 


\section{Figure 11}

Vegetation of the Radiolion alliance

(A) phytocoenose of the Stellario uliginosae-Isolepidetum setaceae association. (B, C, D) phytoceonoses of the Centunculo minimi-Anthoceretum punctati association: a patch of the Hyperico humifusi-Spergularietum rubrae, phytocoenose of the Panico-Illecebretum verticillati association. $(G)$ a patch of Cerastio dubii-Ranunculetum sardoi. (H) a community of Montia arvensis (Photos by S. Rosadziński). 


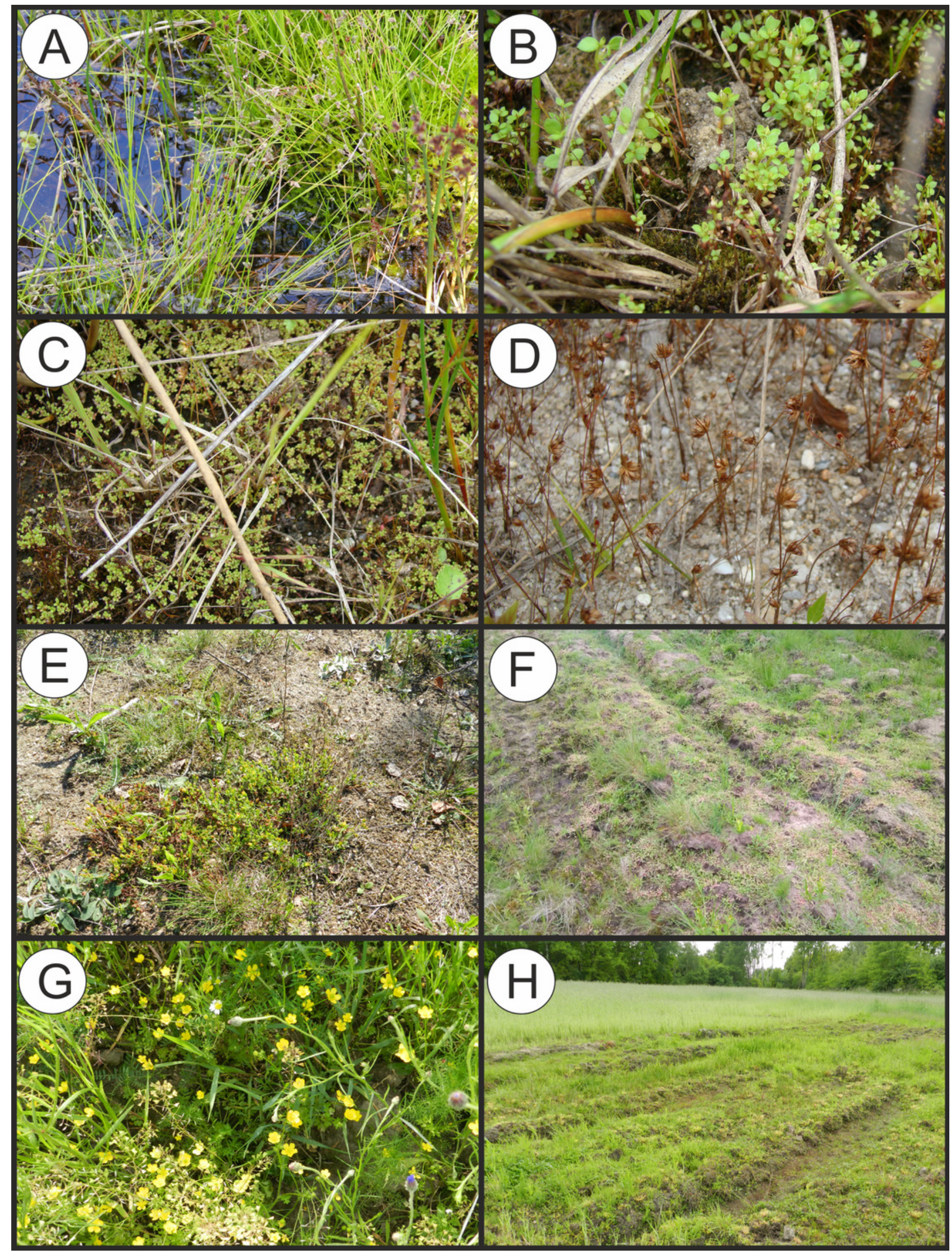




\section{Figure 12}

DCA ordination diagram of samples of Radiolion linoidis plant communities

The first two ordination axes explain $26.8 \%$ and $36.3 \%$ of the total species-environment relations variability, and additionally explain $5.5 \%$ and $9.0 \%$ of the total species variability $(n=223)$. Colored dots mark the centroids. (A) Stellario uliginosae-Isolepidetum setaceae. (B) Centunculo minimi-Anthoceretum punctati. (C) Hyperico humifusi-Spergularietum rubrae. (D) Panico-Illecebretum verticillati. (E) Cerastio-Ranunculetum sardoi. (F) Community with Montia arvensis. 


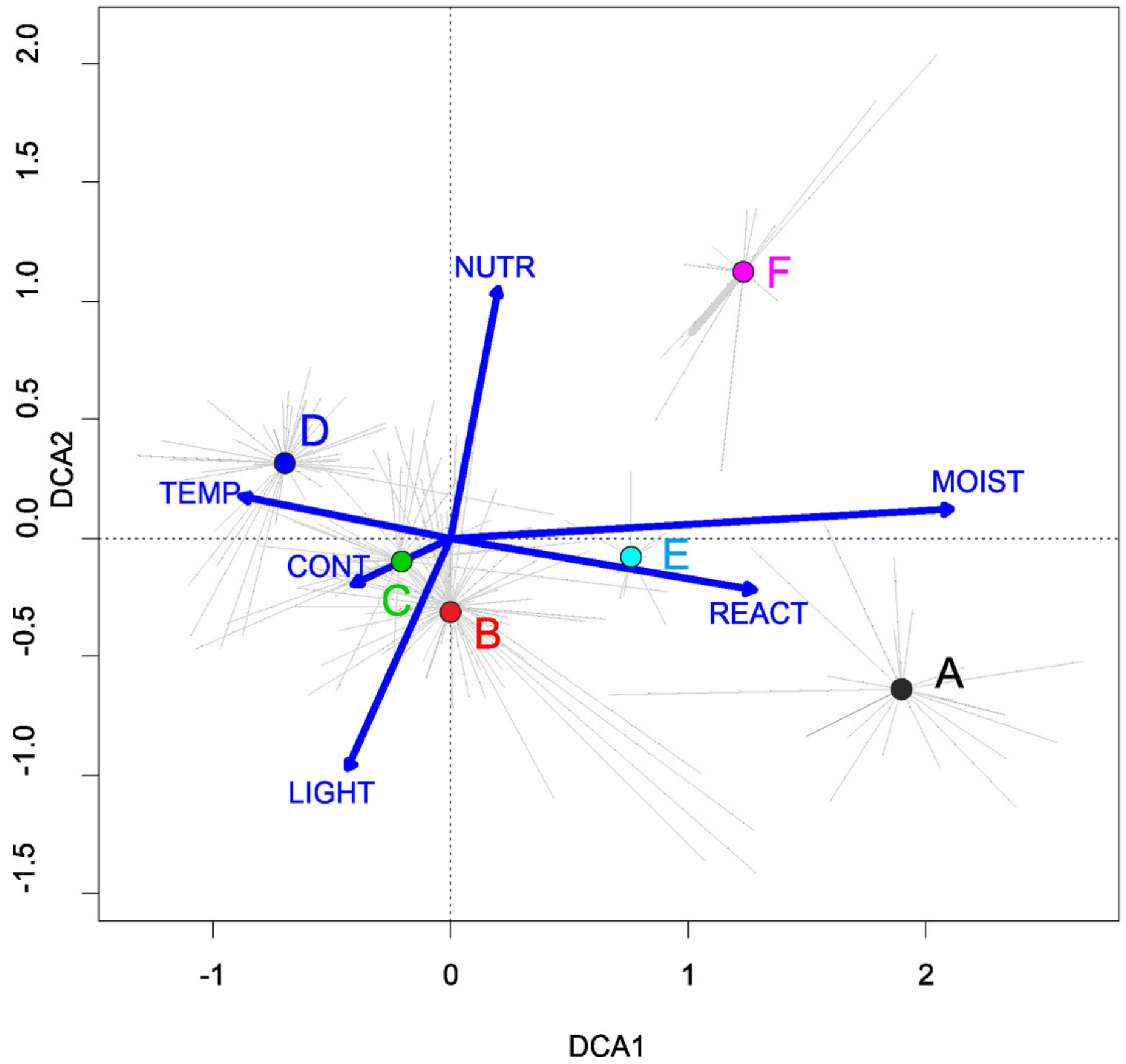

